\title{
New 1,2,3-Triazoles from (R)-Carvone: Synthesis, DFT Mechanistic Study and In Vitro Cytotoxic Evaluation
}

\author{
Ali Oubella ${ }^{1}$, Abdoullah Bimoussa ${ }^{1}$, Abdellah N'ait Oussidi ${ }^{1}$, Mourad Fawzi ${ }^{1}$, Aziz Auhmani ${ }^{1}$, Hamid Morjani ${ }^{2}$, \\ Abdelkhalek Riahi ${ }^{3}$, M'hamed Esseffar ${ }^{1, *}$, Carol Parish ${ }^{4, *}$ and Moulay Youssef Ait Itto ${ }^{1, *}$ (D) \\ 1 Laboratoire de Chimie Moléculaire, Département de Chimie, Faculté des Sciences, Semlalia B.P 2390, \\ Marrakech 40001, Morocco; oubellaali1@gmail.com (A.O.); bimoussa_@hotmail.com (A.B.); \\ docabdellah@gmail.com (A.N.O.); fawzi.mourad93@gmail.com (M.F.); a.auhmani@uca.ac.ma (A.A.) \\ 2 BioSpectroscopie Translationnelle, BioSpecT-EA7506, UFR de Pharmacie, Université de Reims \\ Champagne-Ardenne, 51 Rue Cognacq Jay, CEDEX, 51096 Reims, France; hamid.morjani@univ-reims.fr \\ 3 Equipe MSO, CNRS UMR 7312 Institut de Chimie Moléculaire, Université de Reims Champagne-Ardenne, \\ Bat. Europol'Agro-Moulin de La Housse UFR Sciences B.P., 1039, CEDEX 2, 51687 Reims, France; \\ abdelkhalek.riahi@univ-reims.fr \\ 4 Gottwald Science Center, 28Westhampton Way, University of Richmond, Richmond, VA 23173, USA \\ * Correspondence: esseffar@uca.ac.ma (M.E.); cparish@richmond.edu (C.P.); aititto@uca.ac.ma (M.Y.A.I.)
}

check for updates

Citation: Oubella, A.; Bimoussa, A.; N'ait Oussidi, A.; Fawzi, M.;

Auhmani, A.; Morjani, H.; Riahi, A.; Esseffar, M.; Parish, C.; Ait Itto, M.Y. New 1,2,3-Triazoles from

(R)-Carvone: Synthesis, DFT

Mechanistic Study and In Vitro

Cytotoxic Evaluation. Molecules 2022, 27,769. https://doi.org/10.3390/ molecules27030769

Academic Editors: Mihai V. Putz and Ottorino Ori

Received: 15 September 2021

Accepted: 18 October 2021

Published: 25 January 2022

Publisher's Note: MDPI stays neutral with regard to jurisdictional claims in published maps and institutional affiliations.

Copyright: (c) 2022 by the authors. Licensee MDPI, Basel, Switzerland. This article is an open access article distributed under the terms and conditions of the Creative Commons Attribution (CC BY) license (https:// creativecommons.org/licenses/by/ $4.0 /)$.

\begin{abstract}
Aseries of novel 1,4-disubstituted 1,2,3-triazoles were synthesized from an (R)-carvone terminal alkyne derivative via a $\mathrm{Cu}(\mathrm{I})$-catalyzed azide-alkyne cycloaddition reaction using $\mathrm{CuSO}_{4}, 5 \mathrm{H}_{2} \mathrm{O}$ as the copper (II) source and sodium ascorbate as a reducing agent which reduces $\mathrm{Cu}$ (II) into $\mathrm{Cu}$ (I). All the newly synthesized 1,2,3-triazoles $\mathbf{9 a}-\mathbf{h}$ were fully identified on the basis of their HRMS and NMR spectral data and then evaluated for their cell growth inhibition potential by MTS assay against HT-1080 fibrosarcoma, A-549 lung carcinoma, and two breast adenocarcinoma (MCF-7 and MDA-MB-231) cell lines. Compound 9d showed notable cytotoxic effects against the HT-1080 and MCF-7 cells with $\mathrm{IC}_{50}$ values of 25.77 and $27.89 \mu \mathrm{M}$, respectively, while compound 9c displayed significant activity against MCF-7 cells with an $\mathrm{IC}_{50}$ value of $25.03 \mu \mathrm{M}$. Density functional calculations at the B3LYP / 6-31G* level of theory were used to confirm the high reactivity of the terminal alkyne as a dipolarophile. Quantum calculations were also used to investigate the mechanism of both the uncatalyzed and copper (I)-catalyzed azide-alkyne cycloaddition reaction (CuAAC). The catalyzed reaction gives complete regioselectivity via a stepwise mechanism streamlining experimental observations. The calculated free-energy barriers $4.33 \mathrm{kcal} / \mathrm{mol}$ and $29.35 \mathrm{kcal} / \mathrm{mol}$ for the $1,4-$ and 1,5-regioisomers, respectively, explain the marked regioselectivity of the $\mathrm{CuAAC}$ reaction.
\end{abstract}

Keywords: (R)-carvone; 1,2,3-triazole; DFT calculations; regioselectivity; cytotoxic activity

\section{Introduction}

Cancer is a significant public health issue and has become the leading cause of death worldwide [1]. One of the hallmarks of cancer is the ability of some tumor cells to evolve during the epithelial mesenchymal transition and to acquire both migration and invasion properties. These two characteristics are the most important key factors in metastasis [2] and often lead to poor prognosis and treatment failure. For tumor genesis, genetic predisposal and environmental carcinogenic factors are among the leading causes of the most common forms of cancer [3]. Recent advances in therapeutic research have successfully developed new potent anticancer agents capable of targeting tumors with minimal side effects $[4,5]$. Natural compounds have been and are the main source for the development of several anticancer agents [6-10]. Terpenes and their functionalized derivatives, especially heterocyclic analogues, are often used as a source for the preparation of new semi-synthetic compounds displaying various biological properties including anticancer activity [11,12]. 1,2,3-Triazole derivatives of such terpenes have been shown to present a broad spectrum 
of biological properties including antiproliferative, antiretroviral, and antimicrobial activities [13-18]. Recently, nitrogen-containing heterocyclic compounds have attracted considerable attention in the field of anticancer research [19,20]. Among them, 1,2,3-triazolic systems constitute an important class of five-membered heterocyclic compounds that exhibit promising anticancer properties. Significant and interesting properties have been reported for several drugs containing the 1,2,3-triazole moiety, such as cefatrizine $\mathbf{1}$ [21] and seviteronel 2 [22]. As of 2021, some of these molecules such as carboxyamidotriazole or CAI 3 [23] and mubritinib or TAK-165 4 [24] (Scheme 1) are in active clinical trials.

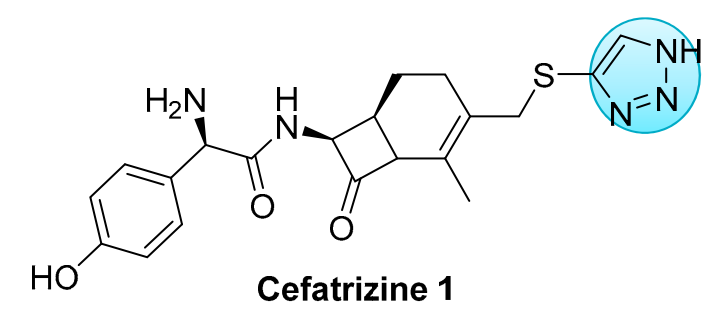<smiles>CCOc1ccc(C(O)(c2ccc3cc(OC(F)F)c(OC(F)F)cc3c2)C(C)C)cn1</smiles><smiles>NC(=O)c1ncnn1Cc1cc(Cl)c(C(=O)c2ccc(Cl)cc2)c(Cl)c1</smiles>

Carboxymidotriazole (CAI) 3

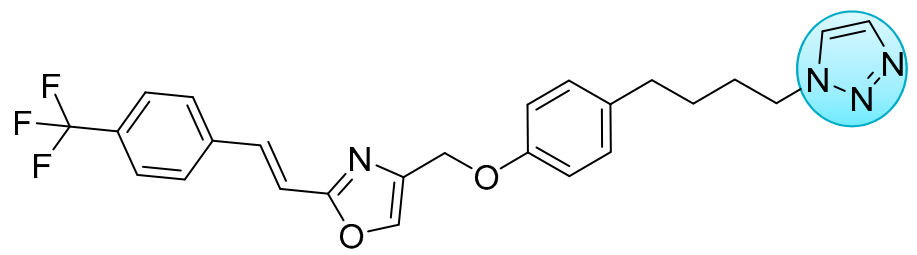

Mubritinib (TAK-165) 4

Scheme 1. Potential anticancer drugs based on 1,2,3-triazole nucleus.

In terms of stability, 1,2,3-triazoles are highly stable under oxidative and acidic or basic hydrolysis conditions [25]. 1,2,3-Triazoles possess a significant dipole moment ( 5 Debye) and have the ability to form hydrogen bonds, which facilitates binding with the biomolecular targets and improves their aqueous solubility [26,27]. 1,2,3-Triazoles are generally prepared by an azide-alkyne cycloaddition reaction. However, this synthetic procedure, first proposed by Huisgen [28], often leads to two regioisomers: 1,4- and 1,5-disubstituted 1,2,3-triazoles. It was only after the introduction of the click chemistry concept by Sharpless [29], which has developed the stereospecific synthesis of 1,4-regioisomer (in the presence of $\mathrm{Cu}$ (I) catalyst at room temperature), that this methodology has gained great interest in synthetic and medicinal chemistry. The efficient and regiospecific alkyne-azide-click reaction, also known as the $\mathrm{Cu}$-catalyzed Alkyne-Azide Cycloaddition reaction (CuAAC), has become a common approach for the stereoselective synthesis of the 1,4 regioisomer of 1,2,3-triazoles. As a part of our efforts toward the synthesis of new bioactive heterocyclic systems with a basic terpenic skeleton [30-37], we have recently reported the interesting anticancer activities of some 1,4-disubstituted 1,2,3-triazolic compounds newly prepared from Eugenol and (R)carvone monoterpene $[38,39]$. These promising findings prompt us to extend our interest in the synthesis ofother 1,4-disubstituted 1,2,3-tiazoles from another natural monoterpene. In the present work, we report the preparation of several 1,4-disubstituted 1,2,3-triazoles built on an (R)-carvone skeleton, obtained chemospecifically via the regiospecific (CuAAC) reaction of arylazides on a terminal alkyne prepared from natural (R)-carvone. A DFT theoretical study was carried out to account for the peri- and the regiospecificity of the reaction. We have also evaluated their vitro cytotoxic effects of the newly prepared triazolic compounds against four human tumors: HT-1080 fibro sarcoma, A-549 lung carcinoma, and two breast adenocarcinoma (MCF-7 and MDA-MB-231) cell lines.

\section{Result and Discussion}

\subsection{Chemistry}

The terminal alkyne 7 is the required precursor for the synthesis of the target 1,2,3-triazoles. It was synthesized according to the reported two-step procedure [40], starting from (R)- 
carvone 5, which was first transformed into the corresponding oxime 6 (Scheme 2). In the second step, the oxime 6 was alkylated with propargyl bromide in dry acetone, using threeequivalents of potassium carbonate as base. After $5 \mathrm{~h}$ of reactionat room temperature, then purification by liquid chromatography on a silica gel column, we obtained the corresponding terminal alkyne $\mathbf{7}$ in 79\% yield (Scheme 2). The structure of $\mathbf{7}$ was fully identified from its HRMS and NMR spectral data which were in full accordance with the reported ones [40]. Its HRMS spectra showed the corresponding pseudo-molecular ion $[\mathrm{MH}]^{+}$at $m / z=204.1388$ is consistent with its molecular formula $\mathrm{C}_{13} \mathrm{H}_{17} \mathrm{NO}$. Its ${ }^{1} \mathrm{H}$ NMR spectrum exhibited characteristic signals such as two one proton triplets $(J \approx 5 \mathrm{~Hz})$ at $\delta 4.62$ and $\delta 4.69$ due to $\mathrm{O}-\mathrm{CH}_{2}$ and atriplet $(\mathrm{J} \approx 5 \mathrm{~Hz})$ at $\delta 2.38$ due to theacetylenic proton. The same propargyloxy group is revealed in the ${ }^{13} \mathrm{C}$ NMR spectrum by the resonance of the methylenic and acetylenic carbons at $\delta 62.93,74.37$ and $80.20 \mathrm{ppm}$.<smiles>C#CCO/N=C1\C[C@H](C(=O)O)[C@H](C)C=C1C</smiles>

Scheme 2. Synthetic route for the preparation of terminal alkyne 7.

In the subsequent step, the terpenic terminal alkyne 7 was submitted to the $\mathrm{Cu}(\mathrm{I})$ catalyzed azide-alkyne cycloaddition reaction (CuAAC) also named the azide-alkyne-click reaction, which is renowned for its high efficiency and regiospecificity when producing 1,4-disubstituted 1,2,3-triazoles. The reaction was carried out for $6 \mathrm{~h}$ at room temperature, with aromatic azides $\mathbf{8 a}-\mathbf{h}$, using $15 \mathrm{~mol} \%$ of $\mathrm{CuSO}_{4}$ as the copper source, in the presence of sodium ascorbate $(20 \mathrm{~mol} \%)$ acting as a $\mathrm{Cu}^{2+}$ reductant, in EtOH- $\mathrm{H}_{2} \mathrm{O}(1 / 5)$ mixture as the solvent [41].

It should be emphasized that as compound 7 features other dipolarophile moieties such as $\mathrm{C}=\mathrm{N}$ and the two $\mathrm{C}=\mathrm{C}$ double bonds, the cycloaddition reaction could lead to other heteocyclic systems such astetrazoles [42] and/or triazolines [43] (Scheme 3).

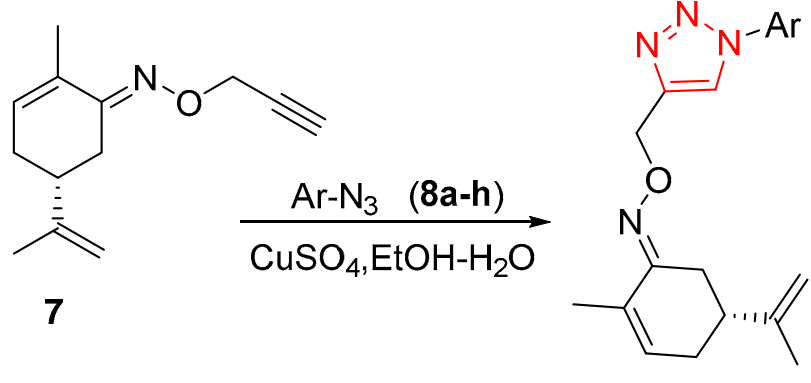

Triazoles<smiles>C#CCON1N=NN([Al])C12C[C@@H](C(=C)C)CC=C2C</smiles>

Tetrazoles
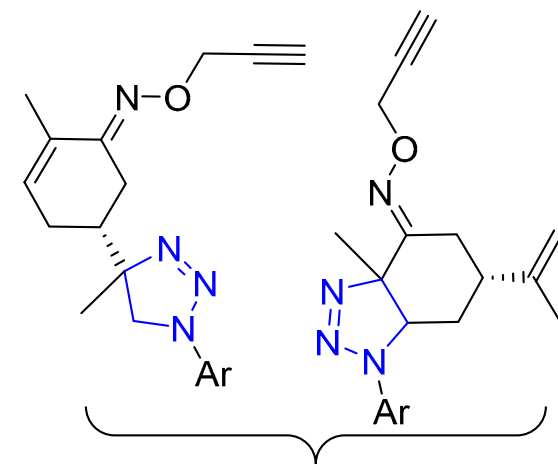

Triazolines

Scheme 3. The obtainable heterocyclic systems from CuAAC reaction of $\mathbf{7}$ with aromatic azides $\mathbf{8 a}-\mathbf{h}$.

After the work up anda silica gel chromatography purification of the reaction mixture, we isolated the corresponding cycloadducts $\mathbf{9 a}-\mathbf{h}$ in good yields (Scheme 4, Table 1). 

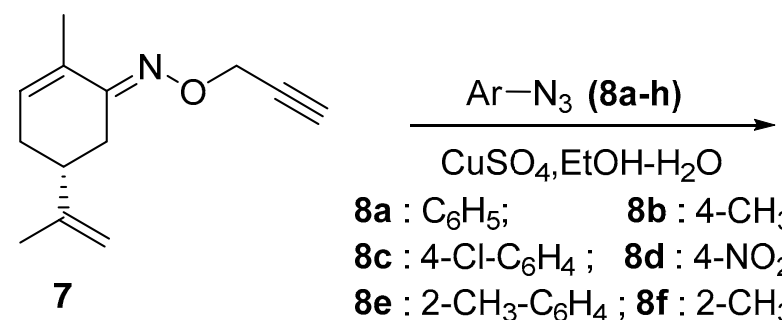

8a: $\mathrm{C}_{6} \mathrm{H}_{5} ; \quad$ 8b: $4-\mathrm{CH}_{3}-\mathrm{C}_{6} \mathrm{H}_{4}$

8c : 4-Cl- $\mathrm{C}_{6} \mathrm{H}_{4} ; 8 \mathrm{~d}: 4-\mathrm{NO}_{2}-\mathrm{C}_{6} \mathrm{H}_{4}$

$8 \mathrm{e}: 2-\mathrm{CH}_{3}-\mathrm{C}_{6} \mathrm{H}_{4} ; \mathbf{8 f}: 2-\mathrm{CH}_{3}-4 \mathrm{Cl}-\mathrm{C}_{6} \mathrm{H}_{3} \quad$ 9a-h

$8 \mathrm{~g}: 4-\mathrm{F}-\mathrm{C}_{6} \mathrm{H}_{4} ; 8 \mathrm{~h}:$ Benzyle

Scheme 4. General schematic for the synthesis of novel 1-4-disubstituted 1,2,3-triazoles 9a-h.

Table 1. Isolated yields and mass spectroscopic data of the terpenic 1,2,3-triazoles $\mathbf{9 a}-\mathbf{h}$.

\begin{tabular}{|c|c|c|c|c|c|}
\hline Product & Formula & Ar & Yield (\%) & {$[\mathrm{MH}]^{+}(\mathrm{a})$} & {$[\mathrm{MH}]^{+}(\mathrm{b})$} \\
\hline $9 a$ & $\mathrm{C}_{19} \mathrm{H}_{22} \mathrm{~N}_{4} \mathrm{O}$ & $\mathrm{C}_{6} \mathrm{H}_{5}$ & 91 & 323.1872 & 323.1873 \\
\hline $9 b$ & $\mathrm{C}_{20} \mathrm{H}_{24} \mathrm{~N}_{4} \mathrm{O}$ & $4-\mathrm{CH}_{3}-\mathrm{C}_{6} \mathrm{H}_{4}$ & 87 & 337.2028 & 337.2031 \\
\hline $9 c$ & $\mathrm{C}_{19} \mathrm{H}_{21} \mathrm{ClN}_{4} \mathrm{O}$ & $4-\mathrm{Cl}-\mathrm{C}_{6} \mathrm{H}_{4}$ & 92 & 357.1482 & 357.1482 \\
\hline $9 d$ & $\mathrm{C}_{19} \mathrm{H}_{21} \mathrm{~N}_{5} \mathrm{O}_{3}$ & $4-\mathrm{NO}_{2}-\mathrm{C}_{6} \mathrm{H}_{4}$ & 88 & 368.1723 & 368.1712 \\
\hline $9 e$ & $\mathrm{C}_{20} \mathrm{H}_{24} \mathrm{~N}_{4} \mathrm{O}$ & $2-\mathrm{CH}_{3}-\mathrm{C}_{6} \mathrm{H}_{4}$ & 82 & 337.2028 & 337.2022 \\
\hline $9 f$ & $\mathrm{C}_{20} \mathrm{H}_{23} \mathrm{ClN}_{4} \mathrm{O}$ & $\begin{array}{c}2-\mathrm{CH}_{3}-4-\mathrm{Cl}- \\
\mathrm{C}_{6} \mathrm{H}_{3}\end{array}$ & 86 & 371.1620 & 371.1629 \\
\hline $9 g$ & $\mathrm{C}_{19} \mathrm{H}_{21} \mathrm{FN}_{4} \mathrm{O}$ & $4-\mathrm{F}-\mathrm{C}_{6} \mathrm{H}_{4}$ & 94 & 341.1778 & 341.1783 \\
\hline $9 \mathrm{~h}$ & $\mathrm{C}_{20} \mathrm{H}_{24} \mathrm{~N}_{4} \mathrm{O}$ & $\mathrm{C}_{6} \mathrm{H}_{5}-\mathrm{CH}_{2}$ & 89 & 337.2028 & 337.2037 \\
\hline
\end{tabular}

(a) Calculated mass; ${ }^{\text {(b) }}$ found mass.

All the new terpenic1,2,3-triazoles $\mathbf{9 a}-\mathbf{h}$ were identified by HRMS and NMR spectroscopic techniques. Indeed, their ESI-HRMS spectra reveal pseudo-molecular ions $[\mathrm{MH}]^{+}$ consistent with the corresponding molecular formula (Table 1).

In their NMR spectra, which show a close similarity, the main feature were the disappearance of the starting acetylenic moiety resonances $\left(\delta{ }^{1} \mathrm{H} 2.38 \mathrm{ppm} ; \delta^{13} \mathrm{C} 74.37\right.$ and $80.20 \mathrm{ppm})$, while we still note signals of both $=\mathrm{C} 3 \mathrm{H}\left(\delta^{1} \mathrm{H} 5.96 \mathrm{ppm} ; \delta^{13} \mathrm{C} 132.82 \mathrm{ppm}\right)$ and $=\mathrm{CH}_{2}$ of the carvone core $\left({ }^{1} \mathrm{H} 4.76 \mathrm{ppm} ; \delta^{13} \mathrm{C} 109.96 \mathrm{ppm}\right)$ (Table 2$)$. These data prove unambiguously that the cycloaddition of the azides $\mathbf{8} \mathbf{a}-\mathbf{h}$ has occurred perispecifically on the acetylenic dipolarophile, leading to the 1,2,3-triazole ring formation. Thelatter is revealed in $\mathbf{9 a}-\mathbf{h}{ }^{1} \mathrm{H}$ NMR spectra by a one proton singlet rangingfrom 7.50 to $8.35 \mathrm{ppm}$ due to the soletriazolic proton and in ${ }^{13} \mathrm{C}$ NMR spectra by the $\mathrm{C} 4^{\prime}$ and $\mathrm{C} 5^{\prime}$ carbons resonances noticed, respectively, at around145.93 and 121.74 ppm (Table 2).

Table 2. NMR characteristic signals of terpenic 1,2,3-triazoles $\mathbf{9 a}-\mathbf{h}$.

\begin{tabular}{ccccccccc}
\hline Compound & $\mathbf{9 a}$ & $\mathbf{9 b}$ & $\mathbf{9 c}$ & $\mathbf{9 d}$ & $\mathbf{9 e}$ & $\mathbf{9 f}$ & $\mathbf{9 g}$ & $\mathbf{9 h}$ \\
\hline $\mathbf{H}-\mathbf{C} 3=\left(\boldsymbol{\delta}^{\mathbf{1}} \mathbf{H}\right)$ & 6.02 & 5.96 & 6.01 & 5.96 & 5.95 & 5.94 & 6.08 & 5.99 \\
$\mathbf{=} \mathbf{3}\left(\boldsymbol{\delta}^{\mathbf{1 3}} \mathbf{C}\right)$ & 132.83 & 132.76 & 132.94 & 133.14 & 132.75 & 130.80 & 132.89 & 132.62 \\
$=\mathrm{CH}_{\mathbf{2}}\left(\boldsymbol{\delta}^{\mathbf{1}} \mathbf{H}\right)$ & 4.75 & 4.67 & 4.73 & 4,70 & 4.69 & 4.69 & 4.76 & 4.76 \\
$=\mathbf{C H}_{\mathbf{2}}\left(\boldsymbol{\delta}^{\mathbf{1 3}} \mathbf{C}\right)$ & 110.17 & 109.94 & 110.37 & 109.99 & 109.96 & 109.97 & 109.96 & 109.91 \\
$\mathbf{H}-\mathbf{C 5}^{\prime}\left(\boldsymbol{\delta}^{\mathbf{1}} \mathbf{H}\right)$ & 8.00 & 7.90 & 7.90 & 8.35 & 7.70 & 7.68 & 7.95 & 7.50 \\
$\mathbf{C 5}^{\prime}\left(\boldsymbol{\delta}^{\mathbf{1 3}} \mathbf{C}\right)$ & 121.74 & 121.32 & 121.20 & 121.05 & 124,66 & 124.89 & 121.46 & 123.10 \\
$\mathbf{C} 4^{\prime}\left(\boldsymbol{\delta}^{\mathbf{1 3}} \mathbf{C}\right)$ & 145.77 & 145.58 & 146.28 & 147.20 & 144.93 & 145.21 & 145.93 & 145.90 \\
\hline
\end{tabular}

In addition to the newly revealed protons and carbons of the triazolic $\mathrm{N}$-aryl groups, the NMR spectra of $\mathbf{9 a}-\mathbf{h}$ exhibit the methylenoxy group $\mathrm{O}-\mathrm{CH}_{2}$ as a two-proton singlet $\left(\delta{ }^{1} \mathrm{H} 5.54-5.26\right)$ and an isolated ${ }^{13} \mathrm{C}$ signal in the region $66.98-67.29 \mathrm{ppm}$. To confirm the wellestablished regiospecificity of the CuAAC reaction for the 1,4-disubstituted 1,2,3-trizoles [29], we have examined the 2D NMR HMBC (Heteronuclear Multiple Bond Correlation) spectrum of 9a (Figure 1), which shows correlations (J4 coupling) between the $\mathrm{C}^{\prime}$ carbon $\left({ }^{13} \mathrm{C} 121.4 \mathrm{ppm}\right)$ and protons of the $\mathrm{N}$-phenyl group $\left(\delta{ }^{1} \mathrm{H} 7,61 \mathrm{ppm}\right)$. All spectral data of the synthesized products are given in the Supporting Experimental Information. 


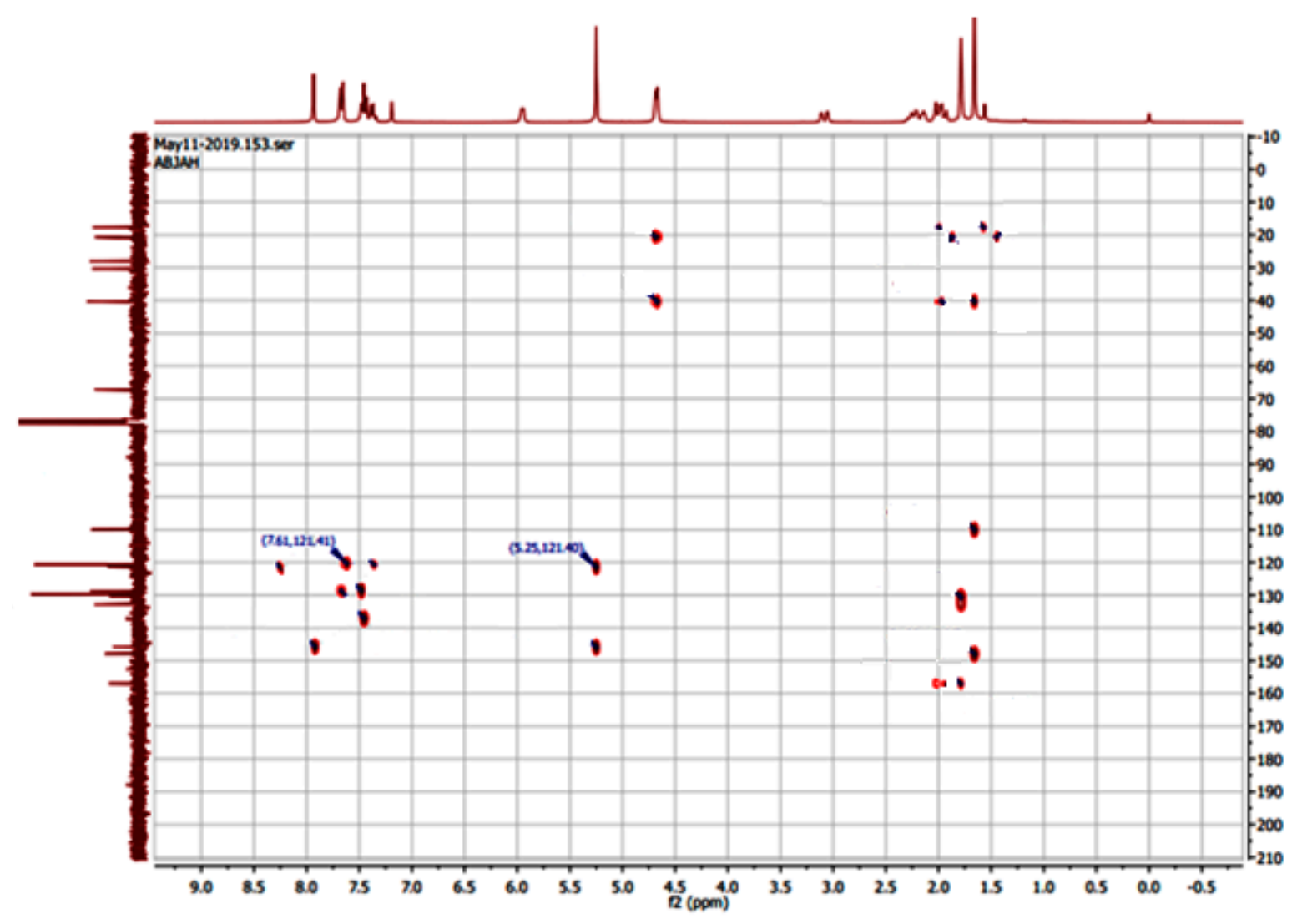

Figure 1. The HMBC correlations of 9 a.

In an attempt to clarify the high periselectivity and regioselectivity of the CuAAC reaction of arylazides $\mathbf{8} \mathbf{a}-\mathbf{h}$ with the carvonic terminal alkyne $\mathbf{7}$, we have carried out a theoretical study using density functional theory (DFT).

\subsection{Theoretical Results and Discussion}

\subsubsection{Analysis of the DFT Reactivity Indices}

It is known from several studies that global indices [44,45] defined in the context of density functional theory (DFT) $[46,47]$ are very useful tools to understand the behavior of polar cycloadditions [44,45]. In Table 3 are presented the static global properties of the reagents, namely the electronic chemical potential $(\mu$, chemical hardness $(\eta)$, global electrophilicity ( $\omega$, and global nucleophilicity $(\mathrm{N})$.

Table 3. Electronic chemical potential $\mu(\mathrm{eV})$, chemical hardness $\eta(\mathrm{eV})$, global electrophilicity $\omega(\mathrm{eV})$, and the nucleophilicity $\mathrm{N}(\mathrm{eV})$ of phenylazide (8a), acetylene carvone derivative (7) and dinucear $\mathrm{Cu}(\mathrm{I})$-acetylide (2Cu(I)-7).

\begin{tabular}{ccccc}
\hline & $\boldsymbol{\mu}$ & $\boldsymbol{\eta}$ & $\boldsymbol{\omega}$ & $\mathbf{N}$ \\
\hline $\mathbf{8 a}$ & -3.62 & 5.16 & 1.27 & 2.92 \\
$\mathbf{7}$ & -3.34 & 5.22 & 1.07 & 3.17 \\
$\mathbf{2 C u}(\mathbf{I})-\mathbf{7}$ & -6.21 & 4.36 & 4.42 & 0.73 \\
\hline
\end{tabular}

The chemical potentials of $\mathbf{8 a}$ and 7 are very close, ( -3.62 and $-3.34 \mathrm{eV}$, respectively), indicating that the reaction will have a non-polar character. This behavior is confirmed by the low values of GEDT computed at the corresponding TSs. The values of Table 3 indicate that arylazide $\mathbf{8 a}$ is a strong electrophile, $\omega=1.27 \mathrm{eV}$ and a moderate nucleophile, $\mathrm{N}=2.92 \mathrm{eV}$, within the electrophilicity [48] and nucleophilicity [49] scales. The acetylene carvone derivative 7 is a marginal electrophile, $\omega=1.07 \mathrm{eV}$, and it is just ontheborder between moderate and strong nucleophiles, $\mathrm{N}=3.17 \mathrm{eV}$. The nucleophilicity difference 
between the two reagents is relatively low $(\Delta \mathrm{N}=0.25 \mathrm{eV})$, suggesting a lack of polar character inthe reaction. However, the coordination of the binuclear $\mathrm{Cu}(\mathrm{I})$ to the acetylene carvone derivative increases its chemical potential $\mu$ almost twice (from -3.34 to $-6.21 \mathrm{eV}$ ). Its electrophilicity also increases from 1.07 to $4.42 \mathrm{eV}$, indicating that coordination converts it to a strong electrophile. On the other hand, its nucleophilicity decreases to $0.73 \mathrm{eV}$ (a marginal nucleophile). This result indicates that the $\mathrm{Cu}(\mathrm{I})$ complex will react as a strong electrophile in the reaction with a strongpolar character.

\subsubsection{Uncatalyzed Reaction of $\mathbf{7}$ and $\mathbf{8 a}$}

As mentioned above, we have carried out a study at the B3LYP/6-31G* level of the uncatalyzed 32CA reaction of $\mathbf{7}$ and $\mathbf{8 a}$. The raw results are presented in Table S1 of the Calculated Supporting Information. As 7 presents four possible dipolarophile sites, the addition of $\mathbf{8 a}$ can take place on each dipolarophile according to the two possible directions, leading to eight regioisomers (Scheme 5). To this end, we have studied all the possible reaction pathways. The analysis of the results for these reactions indicates that they take place along concerted bond formation processes. There are eight TSs, TS1-TS8, associated with the corresponding regioisomers $\mathbf{9 a - 1}$ to $\mathbf{9 a - 8}$, resulting from the addition of 7 on to 8a. All TSs and cycloadducts have been located and characterized. The relative energies, enthalpies and Gibbs energies are summarized in Table S2 of the Calculated Supporting Information. The activation energies in terms of $\Delta \mathrm{G}$ are depicted in Scheme 5.

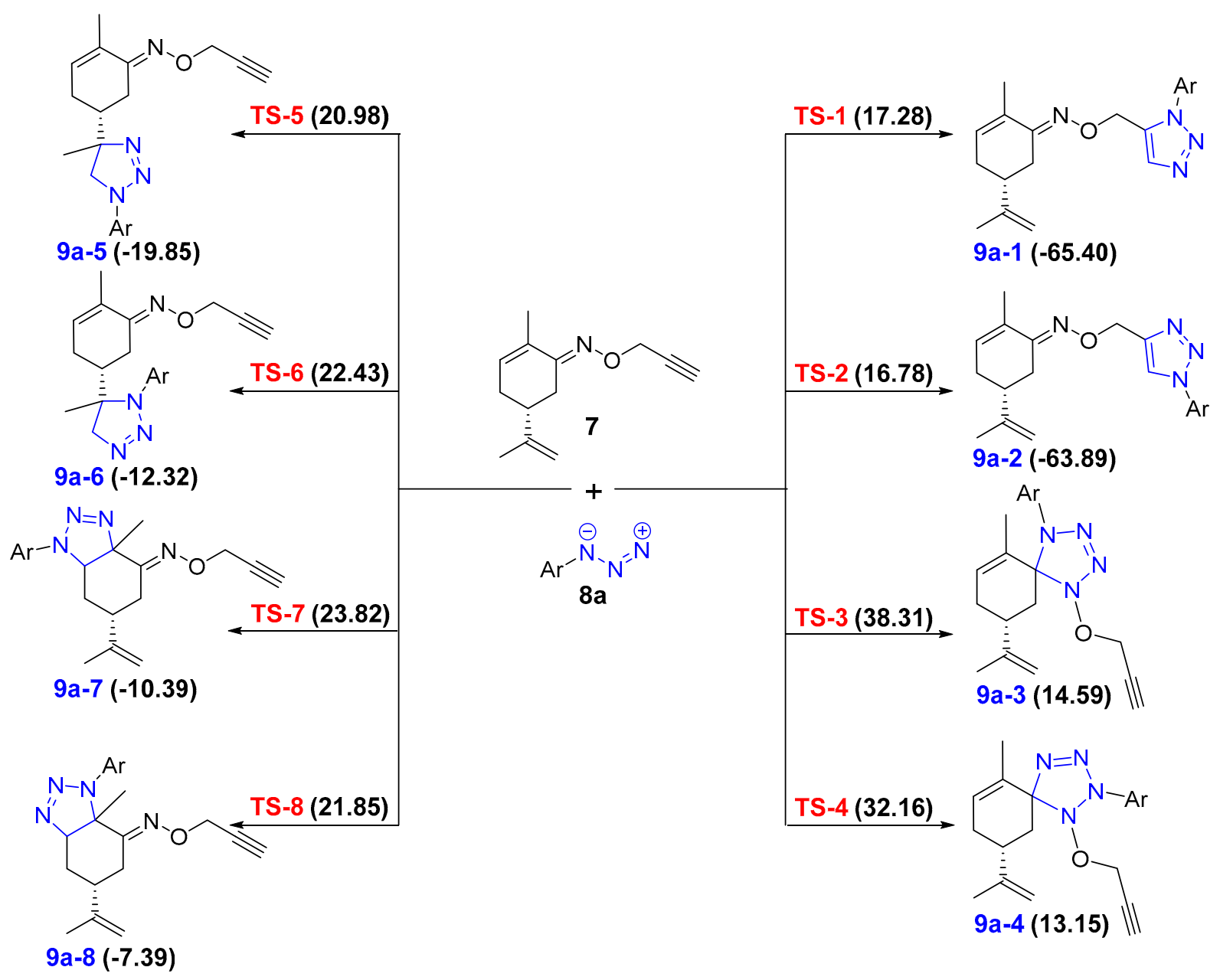

Scheme 5. Activation energies in terms of Gibbs free energies ( $\mathrm{kcal} / \mathrm{mol})$ of all the transition states associated with the corresponding regioisomers of the uncatalyzed 32CA reaction of 7 and $8 \mathbf{a}$. The energy reference is the separated reagents(values in $\mathrm{kcal} / \mathrm{mol}$ ). 
These results show that the reaction takes place with total chemoselectivity. Only the acetylene moiety participates as a dipolarophile to yield the formation of $\mathbf{9 a - 1}$ and 9a-2 as the most favorable cycloadducts. This confirms the high periselectivity of the cycloaddition reaction of 7 with arylazide 8a.The energy barriers associated with the regioisomeric pathways are not very high (ranging between 16.78 and $38.31 \mathrm{kcal} / \mathrm{mol}$ ). The TSs associated with the formation of 9a-1 and 9a-2, (TS-1 and TS-2) are 17.28 and $16.78 \mathrm{kcal} / \mathrm{mol}$, respectively, which are significantly lower than those associated with the formation of the other regioisomers. The corresponding cycloadducts, 9a-1 and 9a-2, are energetically the most exothermic ones $(-65.40$ and $-63.89 \mathrm{kcal} / \mathrm{mol})$. Therefore, these two regioisomers are the kinetic and thermodynamic cycloadducts of the 1,3-dipolar cycloaddition reaction of $\mathbf{7}$ and 8a. However, the free-energy differences $(\Delta \mathrm{G})$ between TS-1 and TS-2 $(0.5 \mathrm{kcal} / \mathrm{mol})$, and between 9a-1 and 9a-2 $(1.51 \mathrm{kcal} / \mathrm{mol})$ are small, explaining the lack of regioselectivity when the 1,3-dipolar cycloaddition reaction of 7 and $8 \mathbf{a}$ is carried out without any catalyst. The geometries of the TS-1 and TS-2 are given in Scheme 6 . The lengths of the C-N forming bonds are 2.172 and $2.217 \AA$ in the case of TS-1 and 2.045 and $2.340 \AA$ in the case of TS-2.

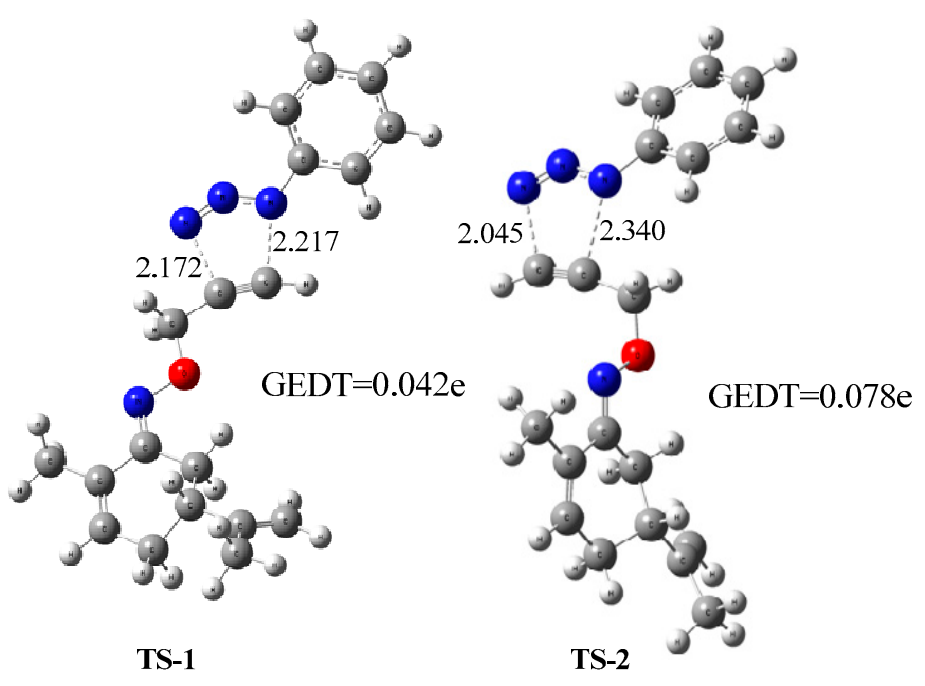

Scheme 6. Optimized geometries of the regioisomericTS-1 and TS-2 associated with the uncatalyzed 1,3-dipolar cycloaddition reaction of $\mathbf{7}$ and 8a. The distances are given in $\AA$.

As can be seen in Scheme 6, the C-N bonds form more synchronously in TS-1 than in TS-2. The degree of bond formation asynchrony can be measured via the difference between the two forming bond lengths, $0.045 \AA$ in TS-1 and $0.295 \AA$ in TS-2. This result indicates that the 1,4-regioisomer process is more asynchronous than the 1,5-regioisomer. In order to analyze the polar or non-polar character of the 32CA reaction between 7 and 8a, the GEDT at the TSs was calculated. The values are reported in Scheme 6. The natural charges at the TSs appear to be shared between the acetylenic derivative 7 and arylazide 8a. The GEDT, which fluxes from alkyne to azide at the TSs, is $0.042 \mathrm{e}$ at TS-1 and 0.078e at TS-2. These low values indicate that the corresponding TSs have non-polar characters.

\subsection{3. $\mathrm{Cu}(\mathrm{I})$-Catalyzed Reaction of $\mathbf{7}$ and $\mathbf{8 a}$}

It is generally known that thermal the 1,3-dipolar cycloaddition of alkynes to azides is not a regiospecific reaction [50]. This can be very advantageous if both regioisomers are desired. Otherwise, it becomes an inconvenience if only one regioisomer is preferred. Analogous reactions have shown that the catalysis is generally regioselective (Scheme 7) [51-57]. The most used catalyst in this type of reaction, which is not expensive, is $\mathrm{Cu}(\mathrm{I})$. The polarization of the terminal triple bond by the covalently bound $\mathrm{Cu}(\mathrm{I})$ catalyzes the 1,3-dipolar cycloaddition, which changes from a concerted reaction into a stepwise addition [58]. 


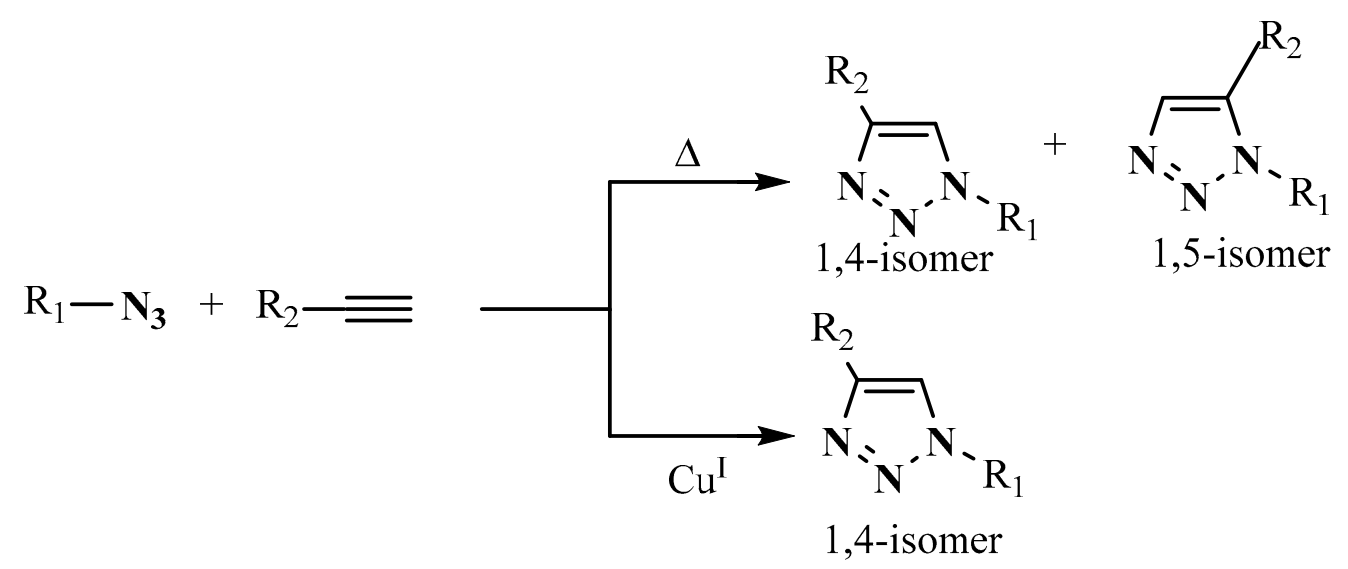

Scheme 7. Thermaland copper-catalyzed cycloaddition reaction of azides and alkynes.

The first proposal for this type of catalyzed reaction was provided by Sharpless and co-workers [52]. $\mathrm{Cu}(\mathrm{I})$ catalyzed the cycloaddition of alkynes and azides (CuAAC) constitute the entry point of click chemistry, which allowed the rapid and regiospecific synthesis of 1,4-disubstituted triazoles, largely overcoming the slowness and the non-regioselectivity of the uncatalyzed reactions according to the classical formalism. The corresponding mechanism was clarified shortly after by Finn et al. [53], who show the participation in the catalytic cycle of a second copper atom, a priori playing a role in the activation of azide functionality. Meanwhile, Straub et al. [59] succeeded in isolating a $\mathrm{Cu}(\mathrm{I})$-triazolide complex, an intermediary of the CuAAC reaction, showing that this reaction does not necessarily imply the presence of a bi-nuclear copper complex [59]. However, other studies have shown that the reaction path with a binuclear copper complex has a lower energy barrier than a mononuclear onewhose activation energy has been found to be in the order of the uncatalyzed path $[56,57]$. For our part and in the same way, we only considered the catalyzed reaction path of the 1,3-dipolar cycloaddition of $\mathbf{7}$ and 8a, involving binuclear coppercomplex. The calculated energies, zero-point vibrational energies (ZPE), thermal corrections, and entropy values of the relevant species are summarized in Table S3 of the Calculated Supporting Information. Table 4 lists their relative energies, $\Delta \mathrm{E}$, enthalpies, $\Delta \mathrm{H}$, and Gibbs energies, $\Delta \mathrm{G}$, relative to the reactants. The reaction involves the initial formation of a reactive complex, $\mathbf{R C}$, which is more stable than the separate reactants. This $\mathbf{R C}$ is built on a $\pi$-coordination of the copper atom to the alkyne promoting his deprotonation and the coordination to the second copper atom. After that, the terminal nitrogen of the azide in 1,4-RC (1,5-RC) binds to the C-2 carbon of the acetylide, forming the six-membered intermediate, 1,4-In (1,5-In) via a first transition state 1,4-TS1 (1,5-TS1) whose activation barrier, in terms of $\Delta \mathrm{G}$, is $4.45 \mathrm{kcal} / \mathrm{mol}(29.47 \mathrm{kcal} / \mathrm{mol})$ (Figure 2). This step appears to be the key mechanistic process of this reaction, allowing the formation of the 1,4-regioisomer $(\mathbf{1}, 4-P)$. The very low activation barrier $(4.45 \mathrm{kcal} / \mathrm{mol})$ leading to 1,4-disubstitued triazole regioisomer explains the enormous acceleration in the rate of this copper-catalyzed process which is considerably lower than that of the uncatalyzed reaction (about $17 \mathrm{kcal} / \mathrm{mol}$ ). From the intermediates, the second step leads to the products via another transition state, 1,4-TS2 (1,5-TS2), with an activation barrier of $13.41 \mathrm{kcal} / \mathrm{mol}(2.31 \mathrm{kcal} / \mathrm{mol})$. This mechanistic behavior is similar to other results which have proven the binuclear nature of the CuAAC mechanism [60]. It is noteworthy that the high exothermic character of the 1,4-disubstitued triazole $(-57.59 \mathrm{kcal} / \mathrm{mol})$ makes it irreversible and the low activation barrier, $(4.45 \mathrm{kcal} / \mathrm{mol})$, which is very easy to overcome, makes it the most kinetically favorable product. When usingethanol as solvent, all stationary points corresponding to the two regioisomers 1,4- and 1,5-disubstituted triazole are moderately changed (see Figure 2 and Table S4 of the Calculated Supplementing Information). In the case of 1,4-TS1 (1,5-TS1), which represents the key of the reaction mechanism, the activation barrier is stabilized 
from 4.35 to $2.98 \mathrm{kcal} / \mathrm{mol}(29.47$ to $22.35 \mathrm{kcal} / \mathrm{mol})$. Consequently, the formation of the most favorable 1,4-regioisomer is subject to a thermodynamic and kinetic control.

Table 4. Relative energies ( $\Delta \mathrm{E}, \mathrm{kcal} / \mathrm{mol})$, enthalpies $(\Delta \mathrm{H}, \mathrm{kcal} / \mathrm{mol})$, entropies $(\Delta \mathrm{S}, \mathrm{kcal} / \mathrm{mol}$, at $\left.25^{\circ} \mathrm{C}\right)$ and Gibbs energies $(\Delta \mathrm{G}, \mathrm{kcal} / \mathrm{mol})$ for all the stationary points relative to the reactants.

\begin{tabular}{ccccc}
\hline Species & $\boldsymbol{\Delta} \mathbf{E}$ & $\boldsymbol{\Delta H}$ & $\mathbf{T} \mathbf{\Delta} \mathbf{S}$ & $\mathbf{\Delta G}$ \\
\hline $\mathbf{8 a}+\mathbf{2 C u}(\mathbf{I})-\mathbf{7}$ & 0 & 0 & 0 & 0 \\
$\mathbf{1 , 4 - R C}$ & -15.39 & -14.79 & -0.0175 & -14.77 \\
$\mathbf{1 , 4 - T S 1}$ & -9.92 & -10.34 & -0.0231 & -10.32 \\
$\mathbf{1 , 4 - I n}$ & -25.11 & -25.67 & -0.0238 & -25.65 \\
$\mathbf{1 , 4 - T S 2}$ & -11.68 & -12.34 & -0.1013 & -12.24 \\
$\mathbf{1 , 4 - P}$ & -57.29 & -57.71 & -0.1150 & -57.59 \\
$\mathbf{1 , 5 - R C}$ & -17.65 & -16.75 & -0.1006 & -16.65 \\
$\mathbf{1 , 5 - T S 1}$ & 12.46 & 12.71 & -0.1067 & 12.82 \\
$\mathbf{1 , 5 - I n}$ & -21.48 & -21.75 & -0.0009 & -21.75 \\
$\mathbf{1 , 5 - T S 2}$ & -18.79 & -19.45 & -0.0094 & -19.44 \\
$\mathbf{1 , 5 - P}$ & -52.37 & -52.78 & -0.1249 & -52.65 \\
\hline
\end{tabular}

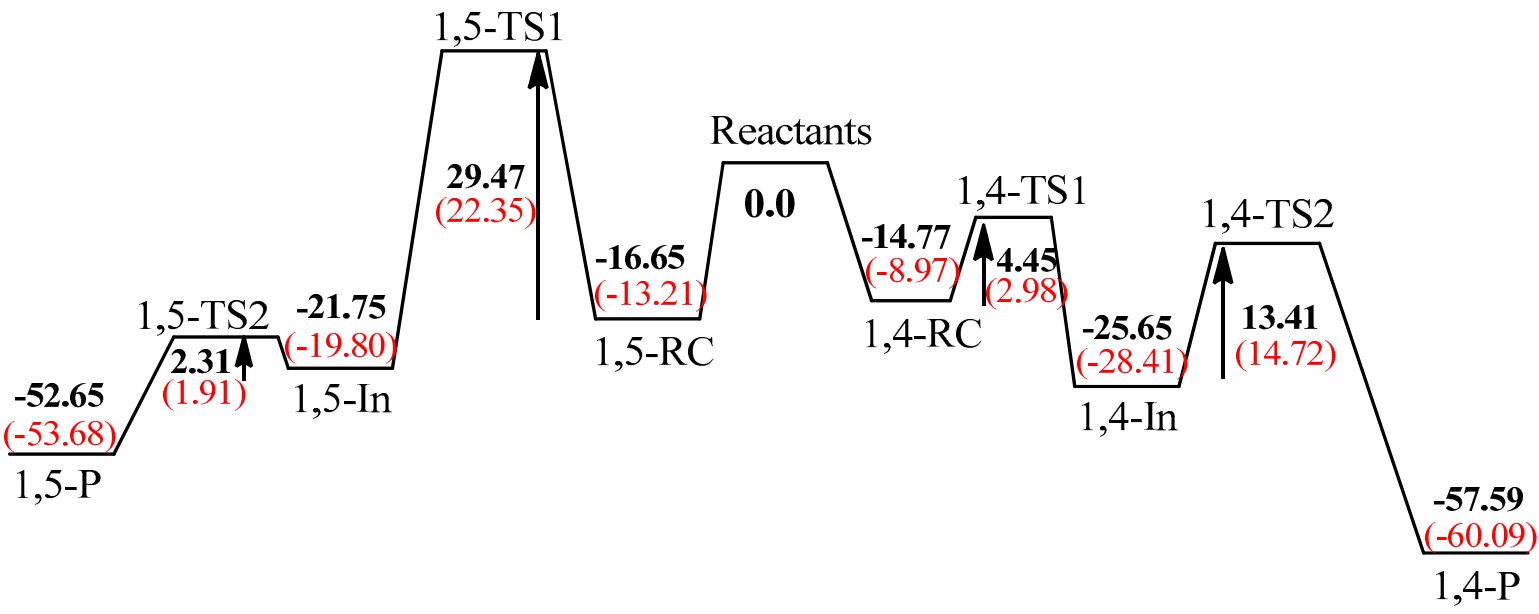

Reaction coordinate

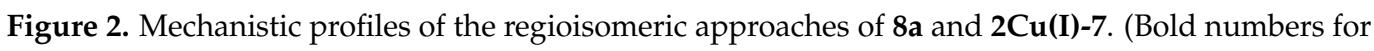
gas phase and numbers between brackets for ethanol as reaction medium).

The computed energetic profiles of the reaction are represented in Figure 2, clearly showing the energetically favorable path leading to the 1,4-regioisomer.The path leading to the 1,5-regioisomer is confronted to the large activation barrier $(29.47 \mathrm{kcal} / \mathrm{mol})$ which is more than six times greater than that leading to the 1,4-regioisomer $(4.45 \mathrm{kcal} / \mathrm{mol})$.

The optimized structures of the stationary points of the reaction paths are shown in Scheme 8. The lengths of the two forming bonds $\mathrm{N}_{1}-\mathrm{C}_{7}$ and $\mathrm{N}_{3}-\mathrm{Cu}_{4}$, at 1,4-TS1, are 2.007 and $1.941 \AA$, respectively. These two bonds evolve into the closure of the six-membered ring with $\mathrm{N}_{1}-\mathrm{C}_{7}=1.421 \AA$ and $\mathrm{N}_{3}-\mathrm{Cu}_{4}=1.893 \AA$, showing that the formation of the reaction intermediate is much more stable than the reactive complex. At 1,4-TS2, associated with the process of opening the six-membered metallacycle and the formation of the five-membered triazolide ring, the lengths of the $\mathrm{N}_{3}-\mathrm{C}_{6}$ and $\mathrm{Cu}_{4}-\mathrm{C}_{6}$ are $2.083 \AA$ and $1.780 \AA$, respectively showing that $\mathrm{Cu}_{4}$ interacts strongly with both $\mathrm{C}_{6}(1.780 \AA)$ and $\mathrm{N}_{3}(2.011 \AA)$. The distance between $\mathrm{C}_{6}$ and $\mathrm{N}_{3}$ evolved from $2.546 \AA$ in the intermediate to $2.083 \AA$, indicating the 
beginning of interaction of the two centers to form the $\mathrm{C}_{6}-\mathrm{N}_{3}$ bond with $1.384 \AA$ at 1,4-P. We also noted a strong interaction between $\mathrm{Cu}_{5}$ and nitrogen $\mathrm{N}_{4}\left(\mathrm{Cu}_{5}-\mathrm{N}_{4}=1.9 \AA\right)$, inducing the formation of a six-membered ring and giving a high stability to the 1,4-regioisomer and consequently a great exothermicity.

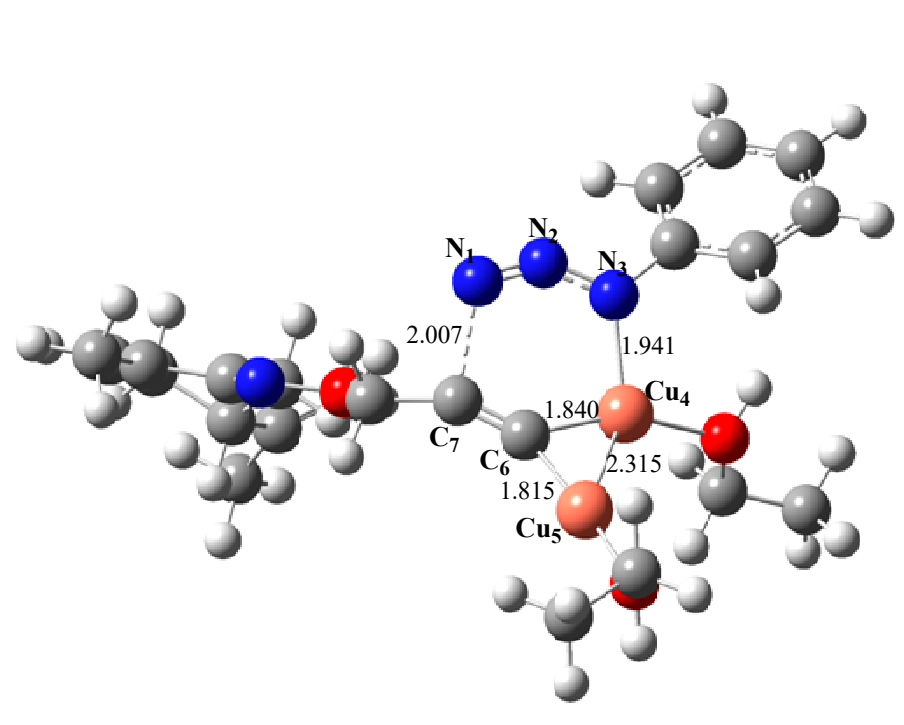

1,4-TS1

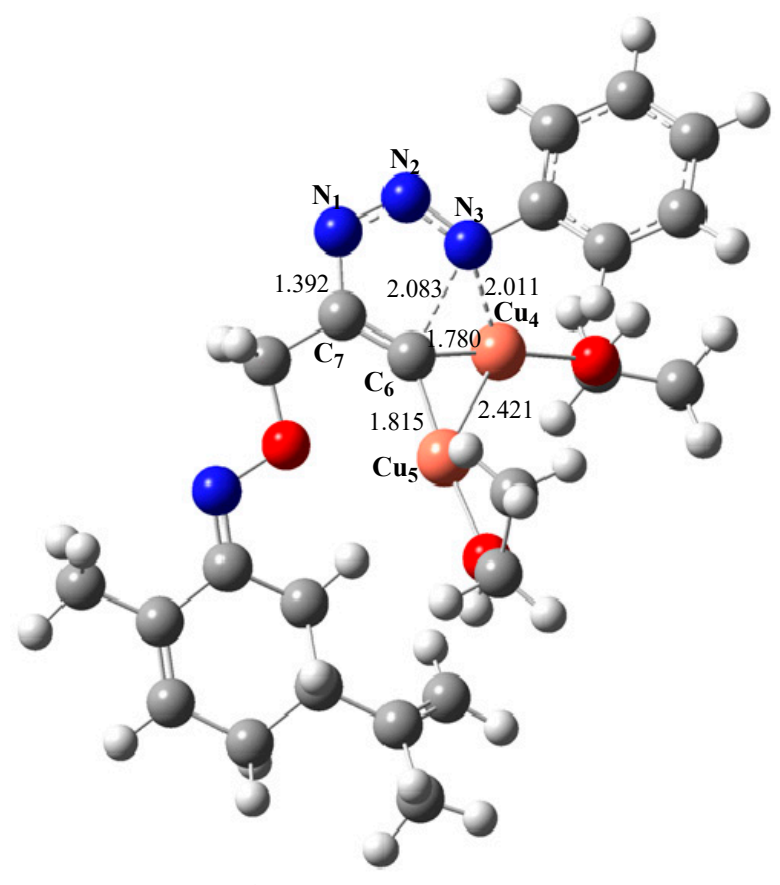

1,4-TS2
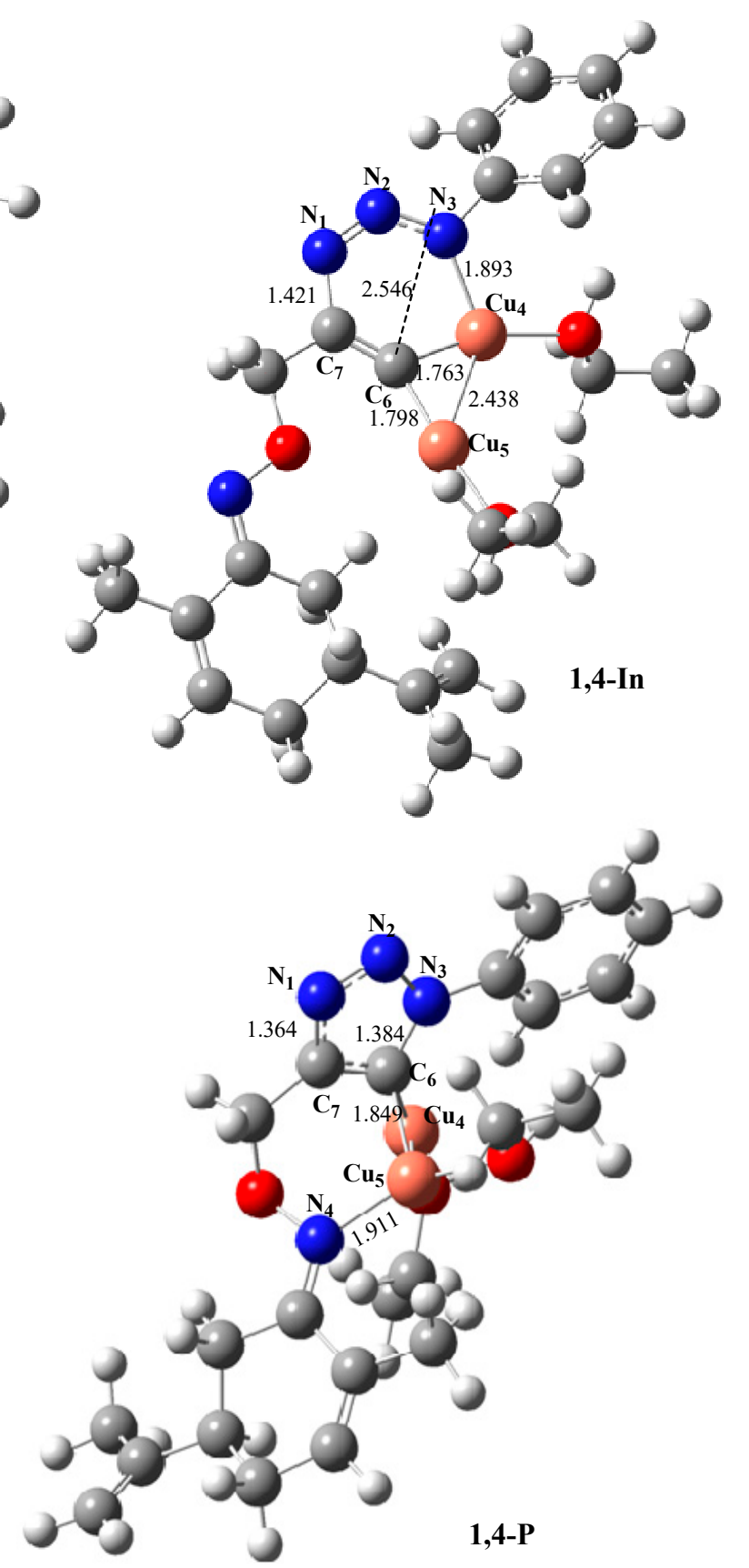

Scheme 8. Optimized geometries of the stationary points in the $2 \mathrm{Cu}(\mathrm{I})$ catalyzed $32 \mathrm{CA}$ reaction. The lengths are given in $\AA$.

\subsection{Anticancer Activity}

(R)-carvone oxime O-propargyl ether $\mathbf{7}$ and the monoterpenic1,2,3-triazoles $\mathbf{9 a}-\mathbf{h}$ were screened for their cell growth inhibitory effects, usingan MTS assay in four human cancer cell lines HT-1080 (fibrosarcoma), A549 (lung carcinoma) and two breast carcinomas (MCF7 and MDAMB-231) [61-63]. The topoisomerase II inhibitor doxorubicin (DOX) was used as a positive control. Data relative to the inhibitory effect $\left(\mathrm{IC}_{50}\right)$ of the synthesized products ( $\mathbf{7}$ and $\mathbf{9 a}-\mathbf{h}$ ) are presented in Table 5 . 
Table 5. In vitro antiproliferative activity of the compounds 7 and $\mathbf{9 a - h}$.

\begin{tabular}{ccccc}
\hline \multirow{2}{*}{ Compound } & \multicolumn{3}{c}{ IC $_{\mathbf{5 0}}(\boldsymbol{\mu M})$} \\
\cline { 2 - 5 } & HT1080 & $\mathbf{A - 5 4 9}$ & MCF-7 & MDA-MB-231 \\
\hline $\mathbf{7}$ & $>100$ & $>100$ & $>100$ & $>100$ \\
$\mathbf{9 a}$ & 85.76 & 71.21 & 55.45 & 72.63 \\
$\mathbf{9 b}$ & 51.9 & $>100$ & 89.75 & $>100$ \\
$\mathbf{9 c}$ & 45.19 & $>100$ & 25.03 & 37.5 \\
$\mathbf{9 d}$ & 25.77 & 30.61 & 27.89 & 45.28 \\
$\mathbf{9 e}$ & $>100$ & $>100$ & $>100$ & $>100$ \\
$\mathbf{9 f}$ & $>100$ & 62.98 & 87.21 & $>100$ \\
$\mathbf{9 g}$ & 30.44 & 51.83 & 30.11 & $>100$ \\
$\mathbf{9 h}$ & 48.69 & $>100$ & 41.54 & 39.45 \\
$\mathbf{9 o x}$ & 5.09 & 6.41 & 5.41 & 5.1 \\
\hline
\end{tabular}

As shown in Table 5, the compounds $\mathbf{9 a}, \mathbf{9 b}, \mathbf{9 e}$ and $\mathbf{9 f}$ were the less active compounds, with $\mathrm{IC}_{50}$ values ranging from 51.90 to $100 \mu \mathrm{M}$. Some of the others were able to induce moderate cell growth inhibitory effects in the different cell lines with $\mathrm{IC}_{50}$ values ranging from 37.50 to $48.69 \mu \mathrm{M}$. However, 9c was highly active against MCF-7 cells with an IC 50 value of $25.03 \mu \mathrm{M}$. The compound $9 \mathrm{~d}$ was more active towards HT-1080, A-549 and MCF-7 cells with respective $\mathrm{IC}_{50}$ values of 25.77 and 30.61 and $27.89 \mu \mathrm{M}$, while $9 \mathrm{~g}$ showed a significant cell growth inhibitory effect on HT-1080 and MCF-7 cells asits corresponding $\mathrm{IC}_{50}$ values were 30.44 and $30.11 \mu \mathrm{M}$, respectively.

\section{Conclusions}

A series of new 1,2,3-triazoles $\mathbf{9 a} \mathbf{a} \mathbf{h}$, built on (R)-carvone skeleton were synthesized, using a $\mathrm{Cu}(\mathrm{I})$-catalyzed 1,3-dipolar cycloaddition reaction between arylazides8a- $\mathbf{h}$ and the monoterpenic terminal alkyne 7 . The [3+2] cycloaddition reaction was revealed to occur efficiently, with high perielectivity and regioselectivity on the carbon-carbon triple bond of 7, affording the corresponding 1,4-disubstituted 1,2,3-triazoles. All the newly synthesized 1,4-disubstituted 1,2,3-triazoles,9a-h, were fully characterized using HRMS and NMR $\left({ }^{1} \mathrm{H}\right.$ and $\left.{ }^{13} \mathrm{C}\right)$ spectroscopic techniques. Furthermore, the high chemoselectivity of this CuAAC reaction was examined by means of DFT mechanistic studies which show that the terminal alkyne is the most reactive of all the dipolarophiles of 7 . In the absence of the catalyst, the studied reaction takes place via a concerted mechanism involving the two energetically very close regioisomers. Meanwhile, the reaction catalyzed by binuclear copper (I) gave access to the only 1,4-substituted 1,2,3-triazole regioisomer via a stepwise mechanism with a very low activation barrier, $4.45 \mathrm{kcal} / \mathrm{mol}(2.98 \mathrm{kcal} / \mathrm{mol}$ in ethanol), rationalizing the experimental observation. On the other hand, all the newly prepared 1,4-disubstituted 1,2,3-triazoles $\mathbf{9} \mathbf{a}-\mathbf{h}$ were evaluated for their anticancer activitiesagainst four selected human cancer cell lines. The tested compounds showed low to good cytotoxic activity against the four investigated cell lines. The compounds $9 \mathrm{c}, \mathbf{9 d}$ and $\mathbf{9 g}$ showed the most interesting cell growth inhibitory effects.

\section{Experimental Section}

\subsection{Materials and Methods}

All chemicals were used as obtained from commercial sources (Aldrich and Acros). Melting points (m.p) were determined using a capillary apparatus and are uncorrected. Analytical thin-layer chromatography (TLC) was performed on plates precoated with E. Merck silica gel 60 F254 to a thickness of $0.25 \mathrm{~mm}$. HRMS were obtained on a Q-TOF micro mass spectrometer. ${ }^{1} \mathrm{H}$ and ${ }^{13} \mathrm{C}$ NMR spectra were recorded in $\mathrm{CDCl}_{3}$ with $500 \mathrm{MHz}$ Bruker Advance Neospectrometer with an Iprobe. Chemical shifts $(\delta)$ are expressed in parts per million (ppm). They were recorded relative to solvent $\mathrm{CDCl}_{3}$ signal $(7.26 \mathrm{ppm}$ and $77.16 \mathrm{ppm})$. The (R)-carvoneoxime6 was prepared according to the reported method [40]. 
The azide derivatives were prepared from the corresponding aniline precursors according to the reported procedures [64].

\subsection{Computational Treatment: Calculations}

Quantum chemistry calculations were carried out using the Gausssian 09 program [65]. Exploration of the potential energy surface (PES) was carried out using the B3LYP functional $[66,67]$ together with the $6-31 G(d, p)$ basis set [68]. Optimizations were carried out using the Berny analytical gradient optimization method $[69,70]$. The stationary points were characterized by frequency computations in order to verify that transition states (TSs) have one and only one imaginary frequency. The IRC paths [71] were traced in order to confirm the energy profiles connecting each TS to the two associated minima of the proposed mechanism using the second order González-Schlegel integration method [72,73]. Values of enthalpies, entropies and free energies were obtained by frequency calculations over B3LYP / 6-31G gas-phase geometries. Thermodynamic data were calculated with the standard statistical thermodynamics at $298.15 \mathrm{~K}$ and $1 \mathrm{~atm}$ [68]. The harmonic vibrational frequencies were determined at the same level to confirm that the optimized structures correspond to real minima of the potential energy surface and to evaluate the zero-point energy (ZPE) corrections, thermal corrections, and entropy values. The ZPE corrections were scaled by anempirical factor of 0.9806 [74]. The global electron density transfer (GEDT) [75] was calculated using the equation GEDT $=\Sigma q$, where $q$ was obtained by a Natural Population Analysis (NPA) [76,77]. As our experimental reactions were carried out in ethanol, we explored the effect of solvent the mechanistic study using ethanol as ligand interacting with the copper atom. The conceptual DFT reactivity indices [46] of the reagents were calculated as follows. The global electrophilicity [78] $\omega$ is given by the expression $\omega=\left(\mu^{2} / 2 \eta\right)$ in terms of the electronic chemical potential $\mu$ and the chemical hardness $\eta$ [79] with $\mu=\left(E_{H}+E_{L}\right) / 2$ and $\eta=\left(E_{L}+E_{H}\right) . E_{H}$ and $E_{L}$ are the HOMO and LUMO energies, respectively. The nucleophilicity $N$ is obtained by $N=E_{H}(N u)-E_{H}(T C E)$. Nucleophilicity is referenced to tetracyanoethylene (TCE) because it presents the lowest HOMO energy in a long series of molecules already investigated in the context of polar cycloadditions [59]. Solvation energies in ethanol as solvent were added as single point calculations using the Polarizable Continuum Model (PCM) [80].

\subsection{Cell Culture}

The human fibrosarcoma cell line HT-1080 (CCL 121) was purchased from Sigma Aldrich (ECACC collection, Saint Quentin Fallavier, France). The human breast adenocarcinoma MCF-7 (HTB-22) and MDA-MB-231(HTB-26) and lung carcinoma A-549 (CCL-185) cell lines were purchased from the American Type Culture Collection (ATCC). Cells were cultured in MEM (HT-1080) and DMEM (A-549, MCF-7 and MDA-MB-231) with Earle salts and Glutamax I (Invitrogen, Cergy-Pontoise, France) supplemented with $10 \%$ fetal bovine serum (Invitrogen) and 1\% penicillin-streptomycin (Invitrogen). Cultures were maintained at $37{ }^{\circ} \mathrm{C}$ in a humidified atmosphere containing $5 \% \mathrm{CO}_{2}(v / v)$. Cells were routinely passaged at preconfluency using $0.05 \%$ trypsin, $0.53 \mathrm{mM}$ EDTA (Invitrogen) and screened for the absence of mycoplasma using PCR method.

\subsection{Cytotoxicity Assay}

The inhibitory effects of the synthesized compounds on cell growth were assessedusing the CellTiter $96{ }^{\circledR}$ cell proliferation assay (MTS) (Promega, Charbonnieres les Bain, France). All the compounds obtained were solubilized in sterile Dimethylsulfoxide (DMSO) and then diluted to the thousandth in the culture medium. Briefly, the cells were plated at a density of 2500 cells/well in $100 \mu \mathrm{L}$ culture medium using 96-well plates and treated with the compounds at different concentrations $(6.25,12.5,25,50$ and $100 \mu \mathrm{M})$. After $24 \mathrm{~h}$, $15 \mu \mathrm{L}$ of MTS dye solution was added in each well. The plates were further incubated for $4 \mathrm{~h}$. Then, $100 \mu \mathrm{L}$ of the solubilization/stop solution was added into each well and the plate was incubated $1 \mathrm{~h}$ at room temperature. The optical density of each well was 
measured at $570 \mathrm{~nm}$ using the microplatereader revelation 96-well multiscanner (Dynex Technologies, Chantilly, VA, USA). Data are represented as a percentage of cell growth relative to untreated cells. The $\mathrm{IC}_{50}$ was defined as the drug concentration required for inhibition of cell growth by $50 \%$.

\subsection{General Procedure for the Preparation of (R)-Carvon-Alkyne 7}

To the solution of (R)-carvoneoxime 6 (9.43 $\mathrm{mmol})$ in dry acetone, potassium carbonate $(28.29 \mathrm{mmol})$ and 3-bromoprop-1-yne $(10.3 \mathrm{mmol})$ wereadded at $25^{\circ} \mathrm{C}$. The reaction mixture was stirred at room temperature. After $4-5 \mathrm{~h}$, the solvent was evaporated under reduced pressure; the resulting residue was diluted with water and extracted withEtOAc $(3 \times 50 \mathrm{~mL})$. The combined organic layers were dried over anhydrous $\mathrm{Na}_{2} \mathrm{SO}_{4}$. After evaporation of the solvent, the crude product was purified by silica gel column chromatography to give the corresponding alkyne 7 .

2-Methyl-5-(prop-1-en-2-yl)cyclohex-2-en-1-one O-prop-2-yn-1-yl oxime (7). Solid; yield-79\%; $\mathrm{mp}-95-97^{\circ} \mathrm{C}$.

${ }^{1} \mathrm{H} \mathrm{NMR}\left(500 \mathrm{MHz} \mathrm{CDCl}_{3}\right) \delta: 1.76\left(3 \mathrm{H}, \mathrm{s}, \mathrm{CH}_{3}\right) ; 1.77\left(3 \mathrm{H}, \mathrm{s}, \mathrm{CH}_{3}\right) ; 1.80-2.25$ and 3.00-3.25 $\left(5 \mathrm{H}, \mathrm{m}, \mathrm{CH}, \mathrm{CH}_{2}\right.$ andCH 2$) ; 2.37(1 \mathrm{H}, \mathrm{t}, \mathrm{J} \approx 5 \mathrm{~Hz}, \mathrm{CH}) ; 4.61\left(2 \mathrm{H}, \mathrm{s}, \mathrm{CH}_{2}\right) ; 4.73\left(2 \mathrm{H}, 2 \mathrm{~s}, \mathrm{H}_{2} \mathrm{C}=\right)$; $5.93(1 \mathrm{H}, \mathrm{m}, \mathrm{HC}=) .{ }^{13} \mathrm{C} \mathrm{NMR}\left(150 \mathrm{MHz}, \mathrm{CDCl}_{3}\right) \delta: 17.77\left(\mathrm{CH}_{3}\right) ; 20.64\left(\mathrm{CH}_{3}\right) ; 27.50$ and 30.09 $\left(\mathrm{CH}_{2}\right.$ and $\left.\mathrm{CH}_{2}\right) ; 40.25(\mathrm{CH}) ; 62.93\left(\mathrm{CH}_{2}\right) ; 74.37(\mathrm{CH}) ; 80.20(\mathrm{C}) ; 110.03\left(\mathrm{H}_{2} \mathrm{C}=\right) ; 130.95$ (C) $132.50(\mathrm{HC}=) ; 148.78(\mathrm{C}) ; 157.91(\mathrm{C}=\mathrm{N})$. HRMS (TOF-MS ES+) $(\mathrm{m} / \mathrm{z})[\mathrm{M}+\mathrm{H}]^{+}$calculated for $\mathrm{C}_{13} \mathrm{H}_{17} \mathrm{NO}$ : 204.1388; found: 204.1388 .

\subsection{General Procedure for the Preparation of Carvone-1,2,3-Triazole $\mathbf{9 a} \boldsymbol{h}$}

To a stirred solution of compound 7 (0.4 mmol) in EtOH: $\mathrm{H}_{2} \mathrm{O}(1: 5, v / v)(5 \mathrm{~mL})$, sodium ascorbate $0.08 \mathrm{mmol}(20 \%), \mathrm{CuSO}_{4} .5 \mathrm{H}_{2} \mathrm{O} 0.06 \mathrm{mmol}(15 \%)$ and the arylazide $(\mathbf{8 a}-\mathbf{h})(1.2 \mathrm{eq}$, $0.48 \mathrm{mmol}$ ) were added in succession and stirred at room temperature for $4-5 \mathrm{~h}$. After completion of the reaction (the progress of the reaction was monitored using TLC), ice cold water $(100 \mathrm{~mL})$ was added to the reaction mixture and extracted with EtOAc $(3 \times 50 \mathrm{~mL})$. The combined organic layers were dried over anhydrous $\mathrm{Na}_{2} \mathrm{SO}_{4}$ and concentrated under reduced pressure. The obtained crude product was purified by silica gel chromatography using Hexane: EtOAc (7:3) to afford the corresponding triazole (9a-h).

(E)-2-methyl-5-(prop-1-en-2-yl)cyclohex-2-en-1-oneO-((1-phenyl-1H-1,2,3-triazol4-yl)methyl) oxime(9a). Solid; yield-91\%; mp127-129 ${ }^{\circ} \mathrm{C}$.

${ }^{1} \mathrm{H}$ NMR (500 MHz, $\left.\mathrm{CDCl}_{3}\right) \delta(\mathrm{ppm}): 1.73\left(3 \mathrm{H}, \mathrm{s}, \mathrm{CH}_{3}\right) ; 1.85\left(3 \mathrm{H}, \mathrm{s}, \mathrm{CH}_{3}\right) ; 1.90-2.40$ and 3.10-3.20 (5H, m, CH, $\mathrm{CH}_{2}$ and $\left.\mathrm{CH}_{2}\right) ; 4.75$ and $4.76\left(2 \mathrm{H}, 2 \mathrm{~s}, \mathrm{H}_{2} \mathrm{C}=\right), 5.32\left(2 \mathrm{H}, \mathrm{s}, \mathrm{O}-\mathrm{CH}_{2}\right)$; $6.02(1 \mathrm{H}, \mathrm{m}, \mathrm{HC}=), 7.40-7.80\left(5 \mathrm{H}, \mathrm{m}, \mathrm{HC}_{\mathrm{Ar}}\right) ; 8.00\left(1 \mathrm{H}, \mathrm{s}, \mathrm{C}_{5^{\prime}} \mathrm{H}\right) .{ }^{13} \mathrm{C} \mathrm{NMR}\left(150 \mathrm{MHz}, \mathrm{CDCl}_{3}\right)$ $\delta(\mathrm{ppm}): 17.72\left(\mathrm{CH}_{3}\right) ; 20.65\left(\mathrm{CH}_{3}\right) ; 27.60$ and $30.80\left(\mathrm{CH}_{2}\right.$ and $\left.\mathrm{CH}_{2}\right) ; 40.33(\mathrm{CH}) ; 67.58(\mathrm{O}-$ $\left.\mathrm{CH}_{2}\right) ; 110.17\left(\mathrm{H}_{2} \mathrm{C}=\right) ; 120.64\left(\mathrm{HC}_{\mathrm{Ar}}\right) ; 121.74\left(\mathrm{CH}_{5^{\prime}}\right) ; 128.71\left(\mathrm{HC}_{\mathrm{Ar}}\right) ; 129.72\left(\mathrm{HC}_{\mathrm{Ar}}\right) ; 130.35(\mathrm{C})$; $132.83(\mathrm{HC}=) ; 137.59\left(\mathrm{C}_{\mathrm{Ar}}\right) ; 145.77(\mathrm{C}) 147.88(\mathrm{C}) ; 156.93(\mathrm{C}=\mathrm{N})$. HRMS (TOF-MS ES+) $(\mathrm{m} / z)$ $[\mathrm{M}+\mathrm{H}]^{+}$calculated for ${ }_{19} \mathrm{H}_{22} \mathrm{~N}_{4} \mathrm{O}: 323.1872$; found: 323.1873 .

(E)-2-methyl-5-(prop-1-en-2-yl)cyclohex-2-en-1-oneO-((1-(p-tolyl)-1H-1,2,3-triazol4-yl)methyl) oxime(9b). Solid; yield-87\%; mp-145-146 ${ }^{\circ} \mathrm{C}$.

${ }^{1} \mathrm{H}$ NMR (500 MHz, $\left.\mathrm{CDCl}_{3}\right) \delta(\mathrm{ppm}): 1.66\left(3 \mathrm{H}, \mathrm{s}, \mathrm{CH}_{3}\right) ; 1.78\left(3 \mathrm{H}, \mathrm{s}, \mathrm{CH}_{3}\right) ; 1.90-2.30$ and 3.10-3.20 (5H, m, CH, $\mathrm{CH}_{2}$ and $\left.\mathrm{CH}_{2}\right) ; 2.35\left(3 \mathrm{H}, \mathrm{s}, \mathrm{CH}_{3}\right) ; 4.67$ and $4.68(2 \mathrm{H}, 2 \mathrm{~s}$, $\left.\mathrm{H}_{2} \mathrm{C}=\right)$, $5.28\left(2 \mathrm{H}, \mathrm{s}, \mathrm{O}-\mathrm{CH}_{2}\right) ; 5.96(1 \mathrm{H}, \mathrm{m}, \mathrm{HC}=), 7.20-7.60\left(4 \mathrm{H}, \mathrm{m}, \mathrm{HC}_{\mathrm{Ar}}\right) ; 7.90(1 \mathrm{H}, \mathrm{s}$, $\left.\mathrm{C}_{5^{\prime}} \mathrm{H}\right) .{ }^{13} \mathrm{C} \mathrm{NMR}\left(150 \mathrm{MHz}, \mathrm{CDCl}_{3}\right) \delta(\mathrm{ppm}): 17.70\left(\mathrm{CH}_{3}\right) ; 20.64\left(\mathrm{CH}_{3}\right) ; 21.10\left(\mathrm{CH}_{3}\right) ; 27.99$ and $30.32\left(\mathrm{CH}_{2}\right.$ and $\left.\mathrm{CH}_{2}\right) ; 40.33(\mathrm{CH}) ; 67.27\left(\mathrm{O}-\mathrm{CH}_{2}\right) ; 109.94\left(\mathrm{H}_{2} \mathrm{C}=\right) ; 120.55\left(\mathrm{HC}_{\mathrm{Ar}}\right) ; 121.32$ $\left(\mathrm{CH}_{5^{\prime}}\right) ; 130.20\left(\mathrm{HC}_{\mathrm{Ar}}\right) ; 132.76(\mathrm{HC}=) ; 130.38(\mathrm{C}) ; 138.80\left(\mathrm{C}_{\mathrm{Ar}}\right) ; 135.30\left(\mathrm{C}_{\mathrm{Ar}}\right) ; 145.58(\mathrm{C}) 146.88$ (C); $156.88(\mathrm{C}=\mathrm{N})$. HRMS (TOF-MS ES+) $(\mathrm{m} / \mathrm{z})[\mathrm{M}+\mathrm{H}]^{+}$calculated for $\mathrm{C}_{20} \mathrm{H}_{24} \mathrm{~N}_{4} \mathrm{O}$ : 337.2028; found: 337.2031 .

(E)-2-methyl-5-(prop-1-en-2-yl)cyclohex-2-en-1-oneO-((1-(4-chlorophenyl)-1H-1,2,3-triazol4-yl)methyl) oxime(9c). Solid; yield-92\%; mp-109-111 ${ }^{\circ} \mathrm{C}$.

${ }^{1} \mathrm{H} \mathrm{NMR}\left(500 \mathrm{MHz}, \mathrm{CDCl}_{3}\right) \delta(\mathrm{ppm}): 1.72\left(3 \mathrm{H}, \mathrm{s}, \mathrm{CH}_{3}\right) ; 1.84\left(3 \mathrm{H}, \mathrm{s}, \mathrm{CH}_{3}\right) ; 1.90-2.40$ and 3.05-3.20 (5H, m, CH, $\mathrm{CH}_{2}$ and $\left.\mathrm{CH}_{2}\right) ; 4.73$ and $4.76\left(2 \mathrm{H}, 2 \mathrm{~s}, \mathrm{H}_{2} \mathrm{C}=\right), 5.31\left(2 \mathrm{H}, \mathrm{s}, \mathrm{O}-\mathrm{CH}_{2}\right)$; 
$6.01(1 \mathrm{H}, \mathrm{m}, \mathrm{HC}=), 7.40-7.80\left(4 \mathrm{H}, \mathrm{m}, \mathrm{HC}_{\mathrm{Ar}}\right) ; 7.90\left(1 \mathrm{H}, \mathrm{s}, \mathrm{C}_{5^{\prime}} \mathrm{H}\right) \cdot{ }^{13} \mathrm{C} \mathrm{NMR}\left(150 \mathrm{MHz}, \mathrm{CDCl}_{3}\right)$ $\delta(\mathrm{ppm}): 17.73\left(\mathrm{CH}_{3}\right) ; 20.65\left(\mathrm{CH}_{3}\right) ; 27.50$ and $30,91\left(\mathrm{CH}_{2}\right.$ and $\left.\mathrm{CH}_{2}\right) ; 40.31(\mathrm{CH}) ; 66.98$ $\left(\mathrm{O}-\mathrm{CH}_{2}\right) ; 110.37\left(\mathrm{H}_{2} \mathrm{C}=\right) ; 121.20\left(\mathrm{CH}_{5^{\prime}}\right) ; 121.76\left(\mathrm{HC}_{\mathrm{Ar}}\right) ; 129.91\left(\mathrm{HC}_{\mathrm{Ar}}\right) ; 130.29\left(\mathrm{C}_{\mathrm{Ar}}\right) ; 132.94$ $(\mathrm{HC}=) ; 134.48\left(\mathrm{C}_{\mathrm{Ar}}\right) ; 131.53(\mathrm{C}) ; 146.28$ (C) $147.85(\mathrm{C}) ; 157.01(\mathrm{C}=\mathrm{N})$. HRMS (TOF-MS ES+) $(m / z)[\mathrm{M}+\mathrm{H}]^{+}$calculated for $\mathrm{C}_{19} \mathrm{H}_{21} \mathrm{ClN}_{4} \mathrm{O}$ : 357.1482; found: 357.1482 .

(E)-2-methyl-5-(prop-1-en-2-yl)cyclohex-2-en-1-one O-((1-(4-nitrophenyl)-1H-1,2,3triazol-4-yl)methyl) oxime(9d). Solid; yield $-88 \%$; mp-131-133 ${ }^{\circ} \mathrm{C}$.

${ }^{1} \mathrm{H}$ NMR $\left(500 \mathrm{MHz}, \mathrm{CDCl}_{3}\right) \delta(\mathrm{ppm}): 1.52\left(3 \mathrm{H}, \mathrm{s}, \mathrm{CH}_{3}\right) ; 1.66\left(3 \mathrm{H}, \mathrm{s}, \mathrm{CH}_{3}\right) ; 1.90-2.30$ and 3.00-3.20 (5H, m, $\mathrm{CH}, \mathrm{CH}_{2}$ and $\left.\mathrm{CH}_{2}\right) ; 4.67$ and $4,70\left(2 \mathrm{H}, 2 \mathrm{~s}, \mathrm{H}_{2} \mathrm{C}=\right), 5.26\left(2 \mathrm{H}, \mathrm{s}, \mathrm{O}^{-\mathrm{CH}_{2}}\right)$; $5.96(1 \mathrm{H}, \mathrm{m}, \mathrm{HC}=) ; 7.80-8.10\left(4 \mathrm{H}, \mathrm{m}, \mathrm{HC}_{\mathrm{Ar}}\right) ; 8.35\left(1 \mathrm{H}, \mathrm{s}, \mathrm{C}_{5^{\prime}} \mathrm{H}\right) .{ }^{13} \mathrm{C} \mathrm{NMR}\left(150 \mathrm{MHz}, \mathrm{CDCl}_{3}\right)$ $\delta$ (ppm): $17.74\left(\mathrm{CH}_{3}\right) ; 20.66\left(\mathrm{CH}_{3}\right) ; 28.00$ and $30.31\left(\mathrm{CH}_{2}\right.$ and $\left.\mathrm{CH}_{2}\right) ; 40.30(\mathrm{CH}) ; 66.97$ $\left(\mathrm{O}_{-} \mathrm{CH}_{2}\right) ; 109.99\left(\mathrm{H}_{2} \mathrm{C}=\right) ; 120.51\left(\mathrm{HC}_{\mathrm{Ar}}\right) ; 121.05\left(\mathrm{CH}_{5^{\prime}}\right) ; 125.51\left(\mathrm{HC}_{\mathrm{Ar}}\right) ; 130.21(\mathrm{C}) ; 133.14$ $(\mathrm{HC}=) ; 141.24\left(\mathrm{C}_{\mathrm{Ar}}\right) ; 146.83\left(\mathrm{C}_{\mathrm{Ar}}\right) ; 147.20(\mathrm{C}) 147.80(\mathrm{C}) ; 157.21(\mathrm{C}=\mathrm{N})$. HRMS (TOF-MS ES+) $(m / z)[\mathrm{M}+\mathrm{H}]^{+}$calculated for $\mathrm{C}_{19} \mathrm{H}_{21} \mathrm{~N}_{5} \mathrm{O}_{3}$ : 368.1723; found: 368.1712 .

(E)-2-methyl-5-(prop-1-en-2-yl)cyclohex-2-en-1-oneO-((1-(o-tolyl)-1H-1,2,3-triazol4-yl)methyl) oxime(9e). Solid; yield $-82 \% ; \mathrm{mp}-120-122{ }^{\circ} \mathrm{C}$.

${ }^{1} \mathrm{H}$ NMR $\left(500 \mathrm{MHz}, \mathrm{CDCl}_{3}\right) \delta(\mathrm{ppm}): 1.66\left(3 \mathrm{H}, \mathrm{s}, \mathrm{CH}_{3}\right) ; 1.77\left(3 \mathrm{H}, \mathrm{s}, \mathrm{CH}_{3}\right) ; 1.90-2.30$ and 3.00-3.20 (5H, m, CH, $\mathrm{CH}_{2}$ and $\left.\mathrm{CH}_{2}\right) ; 2.15\left(3 \mathrm{H}, \mathrm{s}, \mathrm{CH}_{3}\right) ; 4.67$ and $4.69\left(2 \mathrm{H}, 2 \mathrm{~s}, \mathrm{H}_{2} \mathrm{C}=\right), 5.26$ $\left(2 \mathrm{H}, \mathrm{s}, \mathrm{O}-\mathrm{CH}_{2}\right) ; 5.95(1 \mathrm{H}, \mathrm{m}, \mathrm{HC}=), 7.00-7.50(4 \mathrm{H}, \mathrm{m}, \mathrm{HC}$ Ar $) ; 7.70\left(1 \mathrm{H}, \mathrm{s}, \mathrm{C}_{5^{\prime}} \mathrm{H}\right) .{ }^{13} \mathrm{C} \mathrm{NMR}$ $\left(150 \mathrm{MHz}, \mathrm{CDCl}_{3}\right) \delta(\mathrm{ppm}): 17.66\left(\mathrm{CH}_{3}\right) ; 20.65\left(\mathrm{CH}_{3}\right) ; 17.88\left(\mathrm{CH}_{3}\right) ; 27.99$ and $30.32\left(\mathrm{CH}_{2}\right.$ and $\left.\mathrm{CH}_{2}\right) ; 40.34(\mathrm{CH}) ; 67.29\left(\mathrm{O}-\mathrm{CH}_{2}\right) ; 109.96\left(\mathrm{H}_{2} \mathrm{C}=\right) ; 124,66\left(\mathrm{CH}_{5^{\prime}}\right) ; 126.04\left(\mathrm{HC}_{\mathrm{Ar}}\right) ; 126.81$ $\left(\mathrm{HC}_{\mathrm{Ar}}\right) ; 129.79\left(\mathrm{HC}_{\mathrm{Ar}}\right) ; 131.45\left(\mathrm{HC}_{\mathrm{Ar}}\right) ; 130.80\left(\mathrm{C}_{\mathrm{Ar}}\right) ; 132.75(\mathrm{HC}=) ; 133.69(\mathrm{C}) ; 136.59\left(\mathrm{C}_{\mathrm{Ar}}\right)$; 144.93 (C); 147.89 (C); $156.89(\mathrm{C}=\mathrm{N})$. HRMS (TOF-MS ES+) $(\mathrm{m} / \mathrm{z})[\mathrm{M}+\mathrm{H}]^{+}$calculated for $\mathrm{C}_{20} \mathrm{H}_{24} \mathrm{~N}_{4} \mathrm{O}$ : 337.2028; found: 337.2022.

(E)-2-methyl-5-(prop-1-en-2-yl)cyclohex-2-en-1-oneO-((1-(4-chloro-2-methylphenyl)-1H1,2,3-triazol-4-yl)methyl) oxime(9f). Solid; yield-86\%; mp115-117 ${ }^{\circ} \mathrm{C}$.

${ }^{1} \mathrm{H}$ NMR $\left(500 \mathrm{MHz}, \mathrm{CDCl}_{3}\right) \delta(\mathrm{ppm}): 1.66\left(3 \mathrm{H}, \mathrm{s}, \mathrm{CH}_{3}\right) ; 1.75\left(3 \mathrm{H}, \mathrm{s}, \mathrm{CH}_{3}\right) ; 2.13\left(3 \mathrm{H}, \mathrm{s}, \mathrm{CH}_{3}\right)$; 1.90-2.10 and 2.16-3.20 (5H, m, CH, $\mathrm{CH}_{2}$ and $\left.\mathrm{CH}_{2}\right) ; 4.67$ and $4.69\left(2 \mathrm{H}, 2 \mathrm{~s}, \mathrm{H}_{2} \mathrm{C}=\right), 5.26$ $\left(2 \mathrm{H}, \mathrm{s}, \mathrm{O}-\mathrm{CH}_{2}\right) ; 5.94(1 \mathrm{H}, \mathrm{m}, \mathrm{HC}=), 7.10-7.60\left(3 \mathrm{H}, \mathrm{m}, \mathrm{HC}_{\mathrm{Ar}}\right) ; 7.68\left(1 \mathrm{H}, \mathrm{s}, \mathrm{C}_{5^{\prime}} \mathrm{H}\right) .{ }^{13} \mathrm{C} \mathrm{NMR}$ $\left(150 \mathrm{MHz}, \mathrm{CDCl}_{3}\right) \delta(\mathrm{ppm}): 15.38\left(\mathrm{CH}_{3}\right) ; 17.66\left(\mathrm{CH}_{3}\right) ; 20.65\left(\mathrm{CH}_{3}\right) ; 27.98$ and $30.31\left(\mathrm{CH}_{2}\right.$ and $\left.\mathrm{CH}_{2}\right) ; 40.32(\mathrm{CH}) ; 67.18\left(\mathrm{O}-\mathrm{CH}_{2}\right) ; 109.97\left(\mathrm{H}_{2} \mathrm{C}=\right) ; 124.89\left(\mathrm{CH}_{5^{\prime}}\right) ; 124.89\left(\mathrm{HC}_{\mathrm{Ar}}\right) ; 127.12$ $\left(\mathrm{C}_{\mathrm{Ar}}\right) ; 130.80(\mathrm{C}) ; 130.80(\mathrm{HC}=) ; 132.86\left(\mathrm{HC}_{\mathrm{Ar}}\right) ; 136.04\left(\mathrm{C}_{\mathrm{Ar}}\right) ; 137.69\left(\mathrm{C}_{\mathrm{Ar}}\right) ; 145.21(\mathrm{C}) 147.86$ (C); $156.98(\mathrm{C}=\mathrm{N})$. HRMS (TOF-MS ES+) $(\mathrm{m} / \mathrm{z})[\mathrm{M}+\mathrm{H}]^{+}$calculated for $\mathrm{C}_{20} \mathrm{H}_{23} \mathrm{ClN}_{4} \mathrm{O}$ : 371.1620; found: 371.1629 .

(E)-2-methyl-5-(prop-1-en-2-yl)cyclohex-2-en-1-oneO-((1-(4-fluorophenyl)-1H-1,2,3triazol-4-yl)methyl) oxime (9g). Solid; yield-94\%; mp-130-132 ${ }^{\circ} \mathrm{C}$.

${ }^{1} \mathrm{H}$ NMR $\left(500 \mathrm{MHz}, \mathrm{CDCl}_{3}\right) \delta(\mathrm{ppm}): 1.72\left(3 \mathrm{H}, \mathrm{s}, \mathrm{CH}_{3}\right) ; 1.85\left(3 \mathrm{H}, \mathrm{s}, \mathrm{CH}_{3}\right) ; 1.90-2.40$ and 3.10-3.20 (5H, m, CH, $\mathrm{CH}_{2}$ and $\left.\mathrm{CH}_{2}\right) ; 4.73$ and $4.76\left(2 \mathrm{H}, 2 \mathrm{~s}, \mathrm{H}_{2} \mathrm{C}=\right), 5.31\left(2 \mathrm{H}, \mathrm{s}, \mathrm{O}^{-\mathrm{CH}_{2}}\right)$; $6.08(1 \mathrm{H}, \mathrm{m}, \mathrm{HC}=), 7.10-7.80\left(4 \mathrm{H}, \mathrm{m}, \mathrm{HC}_{\mathrm{Ar}}\right) ; 7.95\left(1 \mathrm{H}, \mathrm{s}, \mathrm{C}_{5^{\prime}} \mathrm{H}\right) .{ }^{13} \mathrm{C} \mathrm{NMR}\left(150 \mathrm{MHz}, \mathrm{CDCl}_{3}\right)$ $\delta(\mathrm{ppm}): 17.71\left(\mathrm{CH}_{3}\right) ; 20.64\left(\mathrm{CH}_{3}\right) ; 27.50$ and $30.09\left(\mathrm{CH}_{2}\right.$ and $\left.\mathrm{CH}_{2}\right) ; 40.32(\mathrm{CH}) ; 67.28$ $\left(\mathrm{O}-\mathrm{CH}_{2}\right) ; 109.96\left(\mathrm{H}_{2} \mathrm{C}=\right) ; 116.53\left(\mathrm{HC}_{\mathrm{Ar}}\right) ; 121.46\left(\mathrm{CH}_{5^{\prime}}\right) ; 122.54\left(\mathrm{HC}_{\mathrm{Ar}}\right) ; 130.31(\mathrm{C}) ; 132.89$ $(\mathrm{HC}=) ; 136.73\left(\mathrm{C}_{\mathrm{Ar}}\right) ; 133.39\left(\mathrm{C}_{\mathrm{Ar}}\right) ; 145.93(\mathrm{C}) 147.86(\mathrm{C}) ; 156.97(\mathrm{C}=\mathrm{N})$. HRMS (TOF-MS ES+) $(m / z)[\mathrm{M}+\mathrm{H}]^{+}$calculated for $\mathrm{C}_{19} \mathrm{H}_{21} \mathrm{FN}_{4} \mathrm{O}$ : 341.1778; found: 341.1783.

(E)-2-methyl-5-(prop-1-en-2-yl)cyclohex-2-en-1-oneO-((1-benzyl-1H-1,2,3-triazol4-yl)methyl) oxime(9h). Solid; yield- $89 \%$; $\mathrm{mp}-105-107^{\circ} \mathrm{C}$.

${ }^{1} \mathrm{H}$ NMR $\left(500 \mathrm{MHz}, \mathrm{CDCl}_{3}\right) \delta(\mathrm{ppm}): 1.72\left(3 \mathrm{H}, \mathrm{s}, \mathrm{CH}_{3}\right) ; 1.79\left(3 \mathrm{H}, \mathrm{s}, \mathrm{CH}_{3}\right) ; 1.90-2.40$ and 3.00-3.25 (5H, m, CH, $\mathrm{CH}_{2}$ and $\left.\mathrm{CH}_{2}\right) ; 4.73$ and $4.76\left(2 \mathrm{H}, 2 \mathrm{~s}, \mathrm{H}_{2} \mathrm{C}=\right), 5.22\left(2 \mathrm{H}, \mathrm{s}, \mathrm{CH}_{2}\right)$; $5.54\left(2 \mathrm{H}, \mathrm{s}, \mathrm{O}-\mathrm{CH}_{2}\right) ; 5.99(1 \mathrm{H}, \mathrm{m}, \mathrm{HC}=), 7.25-7.40\left(5 \mathrm{H}, \mathrm{m}, \mathrm{HC}_{\mathrm{Ar}}\right) ; 7.50\left(1 \mathrm{H}, \mathrm{s}, \mathrm{C}_{5^{\prime}} \mathrm{H}\right) .{ }^{13} \mathrm{C}$ NMR (150 MHz, CDCl $) \delta(\mathrm{ppm}): 17.60\left(\mathrm{CH}_{3}\right) ; 20.63\left(\mathrm{CH}_{3}\right) ; 27.94$ and $30.29\left(\mathrm{CH}_{2}\right.$ and $\left.\mathrm{CH}_{2}\right) ; 40.33(\mathrm{CH}) ; 54.09\left(\mathrm{CH}_{2}\right) ; 67.25\left(\mathrm{O}-\mathrm{CH}_{2}\right) ; 109.91\left(\mathrm{H}_{2} \mathrm{C}=\right) ; 123.10\left(\mathrm{CH}_{5^{\prime}}\right) ; 128.05\left(\mathrm{HC}_{\mathrm{Ar}}\right)$; $128.70\left(\mathrm{HC}_{\mathrm{Ar}}\right) ; 129.08\left(\mathrm{HC}_{\mathrm{Ar}}\right) ; 130.38\left(\mathrm{C}_{\mathrm{Ar}}\right) ; 132.62(\mathrm{HC}=) ; 134.69(\mathrm{C}) ; 145.90(\mathrm{C}) 147.90(\mathrm{C})$; $156.74(\mathrm{C}=\mathrm{N})$. HRMS (TOF-MS ES+) $(\mathrm{m} / z)[\mathrm{M}+\mathrm{H}]^{+}$calculated for $\mathrm{C}_{20} \mathrm{H}_{24} \mathrm{~N}_{4} \mathrm{O}: 337.2028$; found: 337.2037 . 
Supplementary Materials: The following are available online, Supporting experimental information, Table S1: The calculated energies (E. a.u). zero-point vibrational energies (ZPE. a.u). thermal corrections (TCE. a.u). entropy values (S. cal $/ \mathrm{mol} / \mathrm{K})$. ZPE corrected energies (Ecorr. a.u). enthalpies (H. a.u). and $\mathrm{T} \mathrm{S} \mathrm{(a.u).} \mathrm{at} 25^{\circ} \mathrm{C}$. for all possible regioisomers of the 32CA between 7 and $8 \mathrm{a}$, Table S2: Energies (E). enthalpies (H) and Gibbs free energies $(\mathrm{G})$ for stationary points of all possible regioisomers of the 32CA between 7 and 8 a relative to the separate reactants. All values are in $\mathrm{kcal} / \mathrm{mol}$, Table S3: The calculated energies (E. a.u), zero-point vibrational energies (ZPE. a.u), thermal corrections (TCE. a.u), entropy values (S. cal/mol/K), ZPE corrected energies (Ecorr. a.u), enthalpies (H. a.u) and T S (a.u). at $25^{\circ} \mathrm{C}$, for the stationary points of the two regioisomers 1,4- and 1,5disubstited triazole of the 32CA between $2 \mathrm{Cu}(\mathrm{I})-7$ and 8a. Table S4: Table S4. Energies (E. a.u), zeropoint vibrational energies (ZPE. a.u), thermal corrections (TCE. a.u), entropy values (S. cal/mol/K), ZPE corrected energies (Ecorr. a.u), enthalpies (H. a.u) and T S (a.u) at $25^{\circ} \mathrm{C}$ calculated at B3LYP/6$31 \mathrm{G}^{*}$ in ethanol as solvent using the PCM model for the stationary points of the two regioisomers 1,4 and 1,5-disubstituted 1,2,3-triazole of the 32CA between $2 \mathrm{Cu}(\mathrm{I})-7$ and $8 \mathrm{a}$.

Author Contributions: A.O., A.B., A.N.O. and M.F., synthesis, A.A. and M.Y.A.I., editing data analysis and interpretation of experimental results, H.M. and A.R. NMR sperctrum and data analysis, M.E. and C.P. editing, theoretical calculations and interpretations. All authors have read and agreed to the published version of the manuscript.

Funding: No funding for this work.

Data Availability Statement: Available from authors.

Conflicts of Interest: The authors declare no conflict of interest.

Sample Availability: Samples of the compounds are available from the authors.

\section{References}

1. Liqiao, S.; Rui, H.; Yanhong, W.; Ying, L.; Ziwen, Y.; Shaoyong, K.; Shi, L.; Hu, R.; Wei, Y.; Liang, Y.; et al. Anthranilic Acid-Based Diamides Derivatives Incorporating Aryl-Isoxazoline Pharmacophore as Potential Anticancer Agents: Design, Synthesis and Biological Evaluation. Eur. J. Med. Chem. 2012, 54, 549-556. [CrossRef]

2. Yuri, L. What Are the Hallmarks of Cancer? Nat. Rev. Cancer 2010, 10, 232-233. [CrossRef]

3. Govind, P. Malnutrition leading to cancer by some environmental hazard. IJRAP 2010, 1, 287-291. Available online: www.ijrap.Net (accessed on 1 September 2021).

4. Yaremenko, I.A.; Syroeshkin, M.A.; Levitsky, D.O.; Fleury, F.; Terent'ev, A.O. Cyclic Peroxides as Promising Anticancer Agents: In Vitro Cytotoxicity Study of Synthetic Ozonides and Tetraoxanes on Human Prostate Cancer Cell Lines. Med. Chem. Res. 2017, 26, 170-179. [CrossRef]

5. Zhou, Y.; Li, W.; Xiao, Y. Profiling of Multiple Targets of Artemisinin Activated by Hemin in Cancer Cell Proteome. ACS Chem. Biol. 2016, 11, 882-888. [CrossRef] [PubMed]

6. Jinwoong, K.; Eun, J.P. Cytotoxic Anticancer Candidates from Natural Resources. Curr. Med. Chem. Anti-Cancer Agents 2002, 2, 485-537. [CrossRef]

7. Sarfaraj, H.M.d.; Sheeba, F.; Saba, A.; Khan, M.S. Marine Natural Products: A Lead for Anti-Cancer. IJMS 2012, 41, 27-39.

8. Vishnu, J.R.; Seema, K. Natural Products of Plant Origin as Anticancer Agents. Drug News Perspect. 2001, 14, 465-482. [CrossRef]

9. Karina, P.; Jean-Francois, B. Marine Natural Products and Related Compounds as Anticancer Agents: An Overview of Their Clinical Status. Anticancer Agents Med. Chem. 2013, 13, 603-631. [CrossRef]

10. Cordero, C.M.; León-González, A.J.; Montaño, J.M.C.; Morón, E.B.; Lopez-Lazaro, M. Pro-Oxidant Natural Products as Anticancer Agents. Curr. Drug Targets 2012, 13, 1006-1028. [CrossRef]

11. Ding, Y.; Guo, H.; Ge, W.; Chen, X.; Li, S.; Wang, M.; Chen, Y.; Zhang, Q. Copper(I) Oxide Nanoparticles Catalyzed Click Chemistry Based Synthesis of Melampomagnolide B-Triazole Conjugates and Their Anti-Cancer Activities. Eur. J. Med. Chem. 2018, 156, 216-229. [CrossRef]

12. Yu, H.; Hou, Z.; Tian, Y.; Mou, Y.; Guo, C. Design, Synthesis, Cytotoxicity and Mechanism of Novel Dihydroartemisinin-Coumarin Hybrids as Potential Anti-Cancer Agents. Eur. J. Med. Chem. 2018, 151, 434-449. [CrossRef] [PubMed]

13. Odds, F.C.; Brown, A.J.P.; Gow, N.A.R. Antifungal Agents: Mechanisms of Action. Trends Microbiol. 2003, 11, 272-279. [CrossRef]

14. Kale, P.; Johnson, L.B. Second-Generation Azole Antifungal Agents. Drugs Today 2005, 41, 91-105. [CrossRef]

15. Geisler, J.; Lønning, P.E. Endocrine Effects of Aromatase Inhibitors and Inactivators in Vivo: Review of Data and Method Limitations. J. Steroid Biochem. Mol. Biol. 2005, 95, 75-81. [CrossRef]

16. Kim, D.-K.; Kim, J.; Park, H.-J. Synthesis and Biological Evaluation of Novel 2-Pyridinyl-[1,2,3]Triazoles as Inhibitors of Transforming Growth Factor B1 Type 1 Receptor. Bioorg. Med. Chem. Lett. 2004, 14, 2401-2405. [CrossRef] 
17. Whiting, M.; Tripp, J.C.; Lin, Y.-C.; Lindstrom, W.; Olson, A.J.; Elder, J.H.; Sharpless, K.B.; Fokin, V.V. Rapid Discovery and Structure-Activity Profiling of Novel Inhibitors of Human Immunodeficiency Virus Type 1 Protease Enabled by the Copper(I)Catalyzed Synthesis of 1,2,3-Triazoles and Their Further Functionalization. J. Med. Chem. 2006, 49, 7697-7710. [CrossRef]

18. Howell, A.; Buzdar, A. Are aromatase inhibitors superior to antiestrogens? J. Steroid Biochem. Mol. Biol. 2005, 93, 237-247. [CrossRef]

19. Tian, Y.; Liang, Z.; Xu, H.; Mou, Y.; Guo, C. Design, Synthesis and Cytotoxicity of Novel Dihydroartemisinin-Coumarin Hybrids via Click Chemistry. Molecules 2016, 21, 758. [CrossRef]

20. Sampad, J.; Shabina, I.; Joice, T.; Sandra, L.; Wim, D. Synthesis and Anticancer Activity of Novel Aza-Artemisinin Derivatives. Bioorg. Med. Chem. 2017, 25, 3671-3676. [CrossRef]

21. Agalave, S.; Maujan, S.R.; Pore, V.S. Click Chemistry: 1,2,3-Triazoles as Pharmacophores. Chem. Asian J. 2011, 6, 2696-2718. [CrossRef]

22. Yin, L.; Hu, Q.; Hartmann, R.W. Recent Progress in Pharmaceutical Therapies for Castration-Resistant Prostate Cancer. Int. J. Mol. Sci. 2013, 14, 13958-13978. [CrossRef]

23. Guo, L.; Ye, C.; Chen, W.; Ye, H.; Zheng, R.; Li, J.; Yang, H.; Yu, X.; Zhang, D. Anti-Inflammatory and Analgesic Potency of Carboxyamidotriazole, a Tumorostatic Agent. J. Pharmcol. Ther. 2008, 325, 10-16. [CrossRef] [PubMed]

24. Baccelli, I.; Gareau, Y.; Lehnertz, B.; Gingras, S.; Spinella, J.-F.; Corneau, S.; Mayotte, N.; Girard, S.; Frechette, M.; Blouin-Chagnon, V.; et al. Mubritinib Targets the Electron Transport Chain Complex I and Reveals the Landscape of OXPHOS Dependency in Acute Myeloid Leukemia. Cancer Cell 2019, 36, 84-99.e8. [CrossRef]

25. Tron, G.C.; Pirali, T.; Billington, R.A.; Canonico, P.L.; Sorba, G.; Genazzani, A.A. Click Chemistry Reactions in Medicinal Chemistry: Applications of the 1,3-Dipolar Cycloaddition between Azides and Alkynes. Med. Res. Rev. 2008, $28,278-308$. [CrossRef] [PubMed]

26. Whiting, M.; Muldoon, J.; Lin, Y.-C.; Silverman, S.M.; Lindstrom, W.; Olson, A.J.; Kolb, H.C.; Finn, M.G.; Sharpless, K.B.; Elder, J.H.; et al. Inhibitors of HIV-1 Protease by Using In Situ Click Chemistry. Angew. Chem. Int. Ed. 2006, 45, 1435-1439. [CrossRef]

27. Horne, W.S.; Yadav, M.K.; Stout, C.D.; Ghadiri, M.R. Heterocyclic Peptide Backbone Modifications in an Alpha-Helical Coiled Coil. J. Am. Chem. Soc. 2004, 126, 15366-15367. [CrossRef] [PubMed]

28. Huisgen, R. Cycloadditions-Definition, Classification, and Characterization. Angew. Chem. Int. Ed. Engl. 1968, 7, 321-328. [CrossRef]

29. Kolb, H.C.; Finn, M.G.; Sharpless, K.B. Click Chemistry: Diverse Chemical Function from a Few Good Reactions. Angew. Chem. Int. Ed. Engl. 2001, 40, 2004-2021. [CrossRef]

30. Bimoussa, A.; Oubella, A.; Hachim, M.E.; Fawzi, M.; Itto, M.Y.A.; Mentre, O.; Ketatni, E.M.; Bahsis, L.; Morjani, H.; Auhmani, A. New enaminone sesquiterpenic: TiCl4-catalyzed synthesis, spectral characterization, crystal structure, Hirshfeld surface analysis, DFT studies and cytotoxic activity. J. Mol. Struct. 2021, 1241, 130622. [CrossRef]

31. Laamari, Y.; Oubella, A.; Bimoussa, A.; El Mansouri, A.-E.; Ketatni, E.M.; Mentre, O.; AitItto, M.Y.; Morjani, H.; Khouili, M.; Auhmani, A. Design, Hemiysnthesis, Crystal Structure and Anticancer activity of 1,2,3-Triazoles derivatives of Totarol. Bioorg. Chem. 2021, 115, 105165. [CrossRef] [PubMed]

32. Fawzi, M.; Laamari, Y.; Koumya, Y.; Oubella, A.; Auhmani, A.; Itto, M.Y.A.; Abouelfida, A.; Riahi, A.; Auhmani, A. Electrochemical and theoretical studies on the corrosion inhibition performance of some synthesized D-Limonene based heterocyclic compounds. J. Mol. Struct. 2021, 1244, 130957. [CrossRef]

33. Oubella, A.; Itto, M.Y.A.; Auhmani, A.; Riahi, A.; Robert, A.; Daran, J.-C.; Morjani, H.; Parish, C.; Esseffar, M. Diastereoselective synthesis and cytotoxic evaluation of new isoxazoles and pyrazoles with monoterpenic skeleton. J. Mol. Struct. 2019, 1198, 126924. [CrossRef]

34. Ríos-Gutiérrez, M.; Domingo, L.R.; Esseffar, M.; Oubella, A.; AitItto, M.Y. Unveiling the Different Chemical Reactivity of Diphenyl Nitrilimine and Phenyl Nitrile Oxide in [3+2] Cycloaddition Reactions with (R)-Carvone through the Molecular Electron Density Theory. Molecules 2020, 25, 1085. [CrossRef] [PubMed]

35. Oubella, A.; AitItto, M.Y.; Auhmani, A.; Riahi, A.; Daran, J.-C.; Auhmani, A. Crystal Structure of (R)-5-[(R)-3-(4-Chlorophenyl)-5Methyl-4,5-Dihydroisoxazol-5-Yl]-2-Methylcyclohex-2-Enone. Acta Cryst. E. 2020, 76, 400-403. [CrossRef]

36. Oubella, A.; Fawzi, M.; Auhmani, A.; Riahi, A.; Morjani, H.; Robert, A.; Itto, M.Y.A. Synthesis and Antitumor Activity of Novel Heterocyclic Systems with Monoterpenic Skeleton Combining Dichlorocyclopropane and 1,3,4-Thiadiazole Nucleus. ChemistrySelect 2020, 5, 6403-6406. [CrossRef]

37. Hachim, M.E.; Oubella, A.; Byadi, S.; Fawzi, M.; Laamari, Y.; Bahsis, L.; Aboulmouhajir, A.; Morjani, H.; Auhmani, A.; AitItto, M.Y. Newly synthesized (R)-carvone-derived 1,2,3-triazoles: Structural, mechanistic, cytotoxic and molecular docking studies. J. Biomol. Stru. Dynam. 2021, 1-14. [CrossRef]

38. Taia, A.; Essaber, M.; Oubella, A.; Aatif, A.; Bodiguel, J.; Jamart-Grégoire, B.; AitItto, M.Y.; Morjani, H. Synthesis, Characterization, and Biological Evaluation of New Heterocyclic Systems 1,2,3-Triazole-Isoxazoline from Eugenol by the Mixed Condensation Reactions. Synth. Commun. 2020, 50, 2052-2065. [CrossRef]

39. Oubella, A.; El Mansouri, A.-E.; Fawzi, M.; Bimoussa, A.; Laamari, Y.; Auhmani, A.; Morjani, H.; Robert, A.; Riahi, A.; Itto, M.Y.A. Thiazolidinone-linked 1,2,3-triazoles with monoterpenic skeleton as new potential anticancer agents: Design, synthesis and molecular docking studies. Bioorg. Chem. 2021, 115, 105184. [CrossRef] 
40. Strub, D.J.; Kula, J.; Sikora, M.; Gibka, J.; Lochyński, S. Synthesis and olfactory evaluation of homologous series of (+)- and (-)-carvone oxime ethers. Flavour Fragr. J. 2015, 31, 81-86. [CrossRef]

41. Allam, M.; Bhavani, A.K.D.; Mudiraj, A.; Ranjan, N.; Thippana, M.; Babu, P.P. Synthesis of Pyrazolo[3,4-d]Pyrimidin-4(5H)-Ones Tethered to 1,2,3-Triazoles and Their Evaluation as Potential Anticancer Agents. Eur. J. Med. Chem. 2018, 156, 43-52. [CrossRef] [PubMed]

42. Myznikov, L.; Vorona, S.; Artamonova, T.; Zevatskii, Y. An Improved Protocol for the Preparation of 5-Substituted Tetrazoles from Organic Thiocyanates and Nitriles. Synthesis 2014, 46, 781-786. [CrossRef]

43. Fantauzzi, S.; Gallo, E.; Caselli, A.; Ragaini, F.; Macchi, P.; Casati, N.; Cenini, S. Origin of the Deactivation in Styrene Aziridination

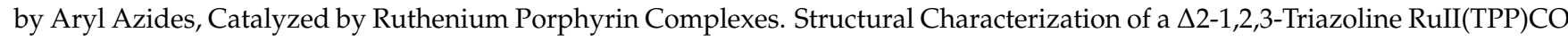
Complex. Organometallics 2005, 24, 4710-4713. [CrossRef]

44. Domingo, L.R.; Aurell, M.J.; Pérez, P.; Contreras, R. Quantitative Characterization of the Local Electrophilicity of Organic Molecules. Understanding the Regioselectivity on Diels-Alder Reactions. J. Phys. Chem. A 2002, 106, 6871-6875. [CrossRef]

45. Pérez, P.; Domingo, L.R.; Aurell, M.J.; Contreras, R. Quantitative Characterization of the Global Electrophilicity Pattern of Some Reagents Involved in 1,3-Dipolar Cycloaddition Reactions. Tetrahedron 2003, 59, 3117-3125. [CrossRef]

46. Geerlings, P.; De Proft, F.; Langenaeker, W. Conceptual Density Functional Theory. Chem. Rev. 2003, 103, 1793-1874. [CrossRef]

47. Domingo, L.R.; Ríos-Gutiérrez, M.; Pérez, P. Applications of the Conceptual Density Functional Theory Indices to Organic Chemistry Reactivity. Molecules 2016, 21, 748. [CrossRef]

48. Domingo, L.R.; Aurell, M.; José, P.P.; Contreras, R. Quantitative Characterization of the Global Electrophilicity Power of Common Diene/Dienophile Pairs in Diels-Alder Reactions. Tetrahedron 2002, 58, 4417-4423. [CrossRef]

49. Jaramillo, P.; Domingo, L.R..; Eduardo, C.; Patricia, P. A Further Exploration of a Nucleophilicity Index Based on the Gas-Phase Ionization Potentials. J. Mol. Struct. Theochem. 2008, 865, 68-72. [CrossRef]

50. Saul, P. The Chemistry of the Carbon-Carbon Triple Bond; John Wiley \& Sons Ltd.: New York, NY, USA, 1978. [CrossRef]

51. Tornøe, C.W.; Christensen, C.; Meldal, M. Peptidotriazoles on Solid Phase: [1,2,3]-Triazoles by Regiospecific Copper(I)-Catalyzed 1,3-Dipolar Cycloadditions of Terminal Alkynes to Azides. J. Org. Chem. 2002, 67, 3057-3064. [CrossRef]

52. Himo, F.; Lovell, T.; Hilgraf, R.; Rostovtsev, V.V.; Noodleman, L.; Sharpless, K.B.; Fokin, V.V. Copper(I)-Catalyzed Synthesis of Azoles. DFT Study Predicts Unprecedented Reactivity and Intermediates. J. Am. Chem. Soc. 2005, 127, 210-216. [CrossRef]

53. Rodionov, V.O.; Fokin, V.V.; Finn, M.G. Mechanism of the Ligand-Free CuI-Catalyzed Azide-Alkyne Cycloaddition Reaction. Angew. Chem. Int. Ed. 2005, 44, 2210-2215. [CrossRef]

54. Rodionov, V.O.; Presolski, S.I.; Díaz, D.D.; Fokin, V.V.; Finn, M.G. Ligand-Accelerated Cu-Catalyzed Azide-Alkyne Cycloaddition: A Mechanistic Report. J. Am. Chem. Soc. 2007, 129, 12705-12712. [CrossRef]

55. Kuang, G.-C.; Guha, P.M.; Brotherton, W.S.; Simmons, J.T.; Stankee, L.A.; Nguyen, B.T.; Clark, R.J.; Zhu, L. Experimental Investigation on the Mechanism of Chelation-Assisted, Copper(II) Acetate-Accelerated Azide-Alkyne Cycloaddition. J. Am. Chem. Soc. 2011, 133, 13984-14001. [CrossRef]

56. Straub, B.F. M-Acetylide $\mu$-Alkenylidene Ligands in “Click” Triazole Syntheses. Chem. Commun. 2007, 37, 3868-3870. [CrossRef]

57. Ahlquist, M.; Fokin, V.V. Enhanced Reactivity of DinuclearCopper(I) Acetylides in Dipolar Cycloadditions. Organometallics 2007, 26, 4389-4391. [CrossRef]

58. Kenkichi, S.; Yasuo, T.; Nobue, H. A convenient synthesis of acetylenes: Catalytic substitutions of acetylenic hydrogen with bromoalkenes, iodoarenes and bromopyridines. Tetrahedron Lett. 1975, 16, 4467-4470. [CrossRef]

59. Nolte, C.; Mayer, P.; Straub, B.F. Isolation of a Copper(I) Triazolide: A “Click” Intermediate. Angew. Chem. Int. Ed. Engl. 2007, 46, 2101-2103. [CrossRef]

60. Ozkilic, Y.; Tuzun, N.S. A DFT Study on the Binuclear CuAAC Reaction: Mechanism in Light of New Experiments. Organometallics 2016, 35, 2589-2599. [CrossRef]

61. EL Mansouri, A.; Oubella, A.; Mehdi, A.; AitItto, M.Y.; Zahouily, M.; Morjani, H.; Lazrek, H.B. Design, Synthesis, Biological Evaluation and Molecular Docking of New 1,3,4-Oxadiazole Homonucleosides and Their Double-Headed Analogs as Antitumor Agents. Bioorg. Chem. 2021, 108, 104558. [CrossRef]

62. El Mansouri, A.; Oubella, A.; Dânoun, K.; Ahmad, M.; Neyts, J.; Jochmans, D.; Snoeck, R.; Andrei, G.; Morjani, H.; Zahouily, M.; et al. Discovery of novel furo[2,3-d]pyrimidin-2-one-1,3,4-oxadiazole hybrid derivatives as dual antiviral and anticancer agents that induce apoptosis. Arch. Pharm. 2021, 354, e210014. [CrossRef]

63. El Mansouri, A.-E.; Oubella, A.; Maatallahd, M.; AitItto, M.Y.; Zahouily, M.; Morjani, H.; Lazrek, H.B. Design, synthesis, biological evaluation and molecular docking of new uracil analogs-1,2,4-oxadiazole hybrids as potential anticancer agents. Bioorg. Med. Chem. Lett. 2020, 30, 127438. [CrossRef]

64. Ashwini, N.; Garg, M.; Mohan, C.D.; Fuchs, J.E.; Rangappa, S.; Anusha, S.; Swaroop, T.R.; Rakesh, K.S.; Kanojia, D.; Madan, V.; et al. Synthesis of 1,2-Benzisoxazole Tethered 1,2,3-Triazoles That Exhibit Anticancer Activity in Acute Myeloid Leukemia Cell Lines by Inhibiting Histone Deacetylases, and Inducing P21 and Tubulin Acetylation. Bioorg. Med. Chem. 2015, 23, $6157-6165$. [CrossRef]

65. Frisch, M.J.; Trucks, G.W.; Schlegel, H.B.; Scuseria, G.E.; Robb, M.A.; Cheeseman, J.R.; Scalmani, G.; Barone, V.; Mennucci, B.; Petersson, G.A.; et al. Gaussian 09; Revision A.02; Gaussian: Wallingford, CT, USA, 2009.

66. Becke, A.D. Density-functional Thermochemistry. III. The Role of Exact Exchange. J. Chem. Phys. 1993, 98, 5648-5652. [CrossRef] 
67. Lee, C.; Yang, W.; Parr, R.G. Development of the Colle-Salvetti Correlation-Energy Formula into a Functional of the Electron Density. Phys. Rev. B. 1988, 37, 785-789. [CrossRef]

68. Wiberg, K.B. Ab Initio Molecular Orbital Theory by W. J. Hehre, L. Radom, P. v. R. Schleyer, and J. A. Pople, John Wiley, New York, 548pp. J. Comput. Chem. 1986, 7, 379. [CrossRef]

69. Schlegel, H.B. Optimization of equilibrium geometries and transition structures. J. Comput. Chem. 1982, 3, 214-218. [CrossRef]

70. Yarkony, D.R. Modern Electronic Structure Theory (In 2 Parts)_Part 1; World Scientific: Singapore, 1995. [CrossRef]

71. Fukui, K. Formulation of the Reaction Coordinate. J. Phys. Chem. 1970, 74, 4161-4163. [CrossRef]

72. Gonzalez, C.; Schlegel, H.B. Reaction Path Following in Mass-Weighted Internal Coordinates. J. Phys. Chem. 1990, 94, 5523-5527. [CrossRef]

73. Gonzalez, C.; Schlegel, H.B. Improved Algorithms for Reaction Path Following: Higher-order Implicit Algorithms. J. Chem. Phys. 1991, 95, 5853-5860. [CrossRef]

74. Scott, A.P.; Radom, L. Harmonic Vibrational Frequencies: An Evaluation of Hartree-Fock, Møller-Plesset, Quadratic Configuration Interaction, Density Functional Theory, and Semiempirical Scale Factors. J. Phys. Chem. 1996, 100, 16502-16513. [CrossRef]

75. Domingo, L.R. A New C-C Bond Formation Model Based on the Quantum Chemical Topology of Electron Density. RSC Adv. 2014, 4, 32415-32428. [CrossRef]

76. Reed, A.E.; Weinstock, R.B.; Weinhold, F. Natural Population Analysis. J. Chem. Phys. 1985, 83, 735-746. [CrossRef]

77. Reed, A.E.; Curtiss, L.A.; Weinhold, F. Intermolecular Interactions from a Natural Bond Orbital, Donor-Acceptor Viewpoint. Chem. Rev. 1988, 88, 899-926. [CrossRef]

78. Robert, G.P.; László, V.S.; Shubin, L. Electrophilicity Index. J. Am. Chem. Soc. 1999, 121, 1922-1924. [CrossRef]

79. Parr, R.G.; Pearson, R.G. Absolute Hardness: Companion Parameter to Absolute Electronegativity. J. Am. Chem. Soc. 1983, 105, 7512-7516. [CrossRef]

80. Cossi, M.; Rega, N.; Scalmani, G.; Barone, V. Energies, structures, and electronic properties of molecules in solution with the C-PCM solvation model. J. Comput. Chem. 2003, 24, 669-681. [CrossRef] [PubMed] 